\title{
Construction 4.0: A Literature Review
}

\author{
Eric Forcael ${ }^{1, *(1)}$, Isabella Ferrari ${ }^{1}$, Alexander Opazo-Vega ${ }^{1}\left(\mathbb{C}\right.$ and Jesús Alberto Pulido-Arcas ${ }^{2}$ \\ 1 Department of Civil and Environmental Engineering, Universidad del Bío-Bío, Concepción 4051381, Chile; \\ iferrari@egresados.ubiobio.cl (I.F.); aopazove@ubiobio.cl (A.O.-V.) \\ 2 Department of Building Construction, Universidad del Bío-Bío, Concepción 4051381, Chile; \\ jpulido@ubiobio.cl \\ * Correspondence: eforcael@ubiobio.cl; Tel.: +56-41-311-1645
}

Received: 14 October 2020; Accepted: 18 November 2020; Published: 23 November 2020

check for updates

\begin{abstract}
The construction industry is experiencing changes in its processes and work methods, and the advancement of new technologies in recent decades has led to a new concept known as Construction 4.0, coined in 2016 in Germany. Since its definition is still diffuse, it was deemed necessary to conduct a review on the publications in this field to grasp how this concept is being understood. For that purpose, a bibliometric analysis was conducted among 260 research articles using seven keywords. The results reveal that the number of publications is growing exponentially, with the USA, the UK, and China being leaders in this field; besides, four technologies are essential to understand Construction 4.0 at present time: 3D printing, big data, virtual reality, and Internet of Things. The results of this review suggest that further reviews should be conducted every 3 years to grasp the rapid evolution of Construction 4.0.
\end{abstract}

Keywords: Construction 4.0; bibliometric analysis; new materials; 3D printing; artificial intelligence and robotics; big data; virtual and augmented reality; Building Information Modeling (BIM); Internet of things

\section{Introduction}

In the 21st century, great technological and scientific advances have been made thanks to Industry 4.0, which mainly focuses on the use of computer and cyber-physical systems [1]. The construction industry has also benefited from this progress, resulting in the term Construction 4.0, which has gained popularity during the last years. First mentioned in 2016 by Roland Berger [2], this concept was primarily based on the awareness by construction firms of the digitization of the construction industry and embraced four key concepts: digital data, automation, connectivity, and digital access. Being a brand-new term, its definition has dynamically evolved during these 4 years, but it can still be defined as a meta-concept that embraces major areas. In such a way, the very recent approach by Sawhney et al. [3] defines Construction 4.0 as a "transformative framework" where 3 transformations take place: industrial production and construction, cyber-physical systems, and digital technologies. Some examples of digital technologies are Building Information Modelling (BIM), Common Data Environment (CDE), unmanned aerial systems, cloud-based project management, Augmented Reality/Virtual Reality (AR/VR), artificial intelligence, cybersecurity, big data and analytics, blockchain, and laser scanner. On the other hand, within the category of cyber-physical systems are robotics and automation, sensors, Internet of Things, workers with wearable sensors, actuators, additive manufacturing, offsite and on-site construction, and equipment with sensors. All these technologies today offer new opportunities for companies that want to increase their competitiveness, the quality of their work, project completion on time, and the new services offered to their customers [4]. Besides, some of these technologies, such as BIM, sensors, and the Internet of Things, have proven to be valuable in achieving the goals for 
a sustainable building environment in the last years [5], along with the great potential and prospects of sustainable decision-making in building technology [6].

These new technologies have greatly impacted an industry that has traditionally been labeled as inefficient, not very productive, and reluctant to technology [7]. On top of that, although automation has been actively and successfully used in different industries since the 1970s, its application in the construction industry is still rare or not fully exploited [8]. In such a way, despite the time span being short-in the field of construction automation, rapid progress has been made in research but has not yet been transferred to the industry - the changes seem remarkable, thus creating the need to conduct a literature review to analyze, synthesize, and discuss the published information, as the significant number of scientific publications in this field may be disperse and difficult to analyze as a whole.

In order to build a theoretical framework, it is deemed necessary to understand where and when Construction 4.0 came from, how its definition has changed over the last years, and how it can be characterized in light of such evolution. For that purpose, this introduction first discusses the origin of the term, then investigates the evolution over time, and finally frames a definition that will be the starting point of this literature review.

As stated before, the term Construction 4.0 did not originate alone but adopted the theoretical framework of a broader concept: Industry 4.0. Known as the "Fourth Industrial Revolution", it has gained fame in recent years since it can influence large industries at the design and manufacturing levels, defining the future of productivity and growth in manufacturing industries. This term originated in Germany, which launched the concept of Industry 4.0 in 2011 as part of its high-tech strategy. Since the concept is quite novel, there is still no agreement on a common definition for it; rather, some authors have pointed out the necessity of a dynamic and comprehensive definition, describing this fourth industrial revolution as a "shift in the manufacturing logic towards an increasingly decentralized, self-regulating approach of value creation, enabled by concepts and technologies such as cyber-physical systems (CPS), Internet of things (IoT), Internet of Services (IOS), cloud computing, or additive manufacturing and smart factories" [9]. From the beginning of industrialization, technological advances have led to paradigm changes that today are called "industrial revolutions": the field of mechanization (the first industrial revolution), the intensive use of electrical energy (the second industrial revolution), and widespread digitalization (the third industrial revolution) [10]. Industry 4.0 facilitates the connection of information, objects, and people, as it creates physical and virtual manufacturing scenarios which enables factories to transform their environment into one of intelligent manufacturing. Industry 4.0 also seeks integrated automation [11] characterized by its dependence on the use of computer systems [1], where the information technologies' trends and unmet needs of Industry 4.0 include manufacturing and industrial big data, which, in turn, give manufacturing analytics an added value.

After this, it is deemed crucial to understand how and when the construction industry started adopting the Industry 4.0 framework. For that purpose, a preliminary bibliographic research was conducted in the Web of Science (WoS/ISI) and Scopus scientific databases to trace back when two keywords were first mentioned in the scientific literature: Industry 4.0 and Construction 4.0. These are considered important because, as mentioned before, the report by Roland Berger related these 2 concepts: Construction 4.0 as a specific application of Industry 4.0.

Therefore, two searches were conducted: First, a search for scientific literature that mentions the concepts "Industry 4.0" and "construction" together and, second, documents where the term "Construction 4.0" appears. The first one is deemed important because it can be clarified when the term Industry 4.0 was first related to the construction industry; the second one is important because it can be clarified when the term Construction 4.0 itself was first used.

The first article that mentions "Industry 4.0" and "construction" together dates back to September 2014 [10], analyzing how automated 3D-printed prototypes could satisfy customer's demand; for that purpose, a pilot project was set. The article that first mentions Construction 4.0 was published in August 2015 by Li and Shi [12], one year before the report by Roland Berger [2]. However, strictly speaking, this paper does not mention "Construction 4.0", but "Dam construction 4.0". Besides, it does not attempt 
to use the term "Construction 4.0" in a broader sense, but to describe a very specific automated process that monitors the construction of dams. Therefore, it can be concluded that 2014 was the first year when the Industry 4.0 was put in relation to the construction industry and 2016 was the first year when Construction 4.0 was mentioned and characterized as a concept. Consequently, as a starting point for this literature review about Construction 4.0, the time span 2014-2019 can be established as a reference.

At the present time, the existing information on Construction 4.0 is deficient since it fails to give an appropriate perspective, which also results in limited analysis of the information. For this reason, it is deemed important to analyze this relatively new concept from a wider and holistic perspective, which foresees that Construction 4.0 is not just traditional construction with technological upgrades but a new way of understanding construction in light of innovation and increased productivity [7].

Accordingly, the definition of Construction 4.0 derives from the foundation of Industry 4.0 but focuses on and relates to the construction sector. Therefore, Construction 4.0 is all technological changes related to the implementation of new work methods which are related to processes, materials, and markets.

One of the possible classifications that would make it possible to characterize the concept of Construction 4.0 is based predominantly on two pillars: digitization of the construction industry and industrialization of construction processes (Figure 1) [13].

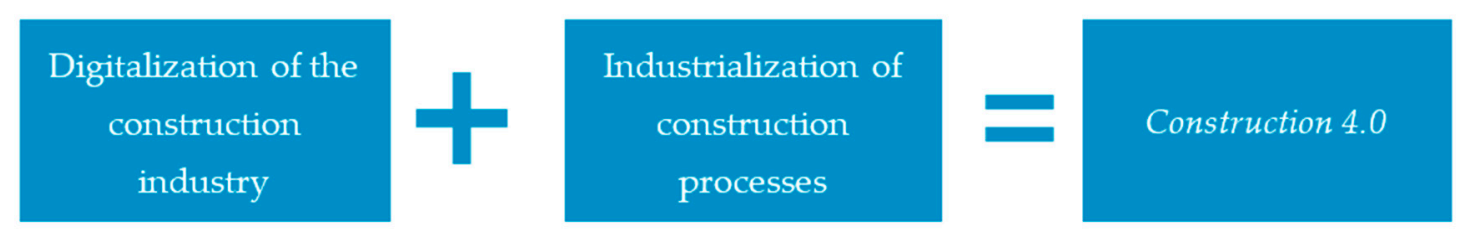

Figure 1. Diagram of Construction 4.0 pillars.

Digitization encompasses the field of data management in digital form through the use of the Internet and software [14]. This technology impacts the whole industry, the companies involved, the environment, and the people. For example, the increase in mobility due to technologies such as laptops, tablets, and smartphones provides and facilitates access to relevant and updated data on digital buildings anytime and anywhere. In fact, virtual technologies are recognized as instruments that are used ever increasingly in the construction industry to deliver successful results in different tasks and processes [15]. In conclusion, investing in new technologies produces improvements in productivity, which is what industries, such as construction, seek the most.

On the other hand, the industrialization of building processes focuses on automated construction, which consists of a new set of technologies and processes that will change how the construction industry is conceived [7], where digital fabrication plays an important role in the productivity of construction processes [8]. Manufacturing processes are included here, since manufacturing companies are also sources of innovation because they can be suppliers and developers of new solutions. In short, construction has focused on advances in technology to seek innovative processes that can improve efficiency through industrialization.

Even though the concept of Construction 4.0 has had a short life, it seems evident that it is attracting remarkable attention, and therefore many attempts are being made to define it, though the definitions are quite diffuse and usually adopt broader concepts from its predecessor: Industry 4.0.

Given this state of affairs, it is deemed necessary to conduct an exhaustive literature review of all aspects related to Construction 4.0. First, a theoretical framework will be established to characterize Construction 4.0 according to the definition by several authors. After this, a literature review will be conducted according to the following objectives: (i) find appropriate keywords that can characterize Construction 4.0 and define them according to the existing literature; (ii) gather bibliographical information on Construction 4.0 using those keywords; (iii) analyze the trend in publications and find relations between keywords, publications, countries, authors, and scientific journals; (iv) propose a 
methodology for an structured literature review; and (v) provide scholars with future directions and guidance to conduct research on Construction 4.0.

\section{Methodology}

The methodology of this study comprises the following steps. First, as an introductory step, the available definitions of Construction 4.0 will be analyzed to propose a general theoretical framework; moreover, a tentative list of keywords to characterize this concept will be proposed based on a preliminary literature review. Second, a more specific literature review will be conducted using those keywords. Third, a bibliometric analysis will be conducted in the following basis: keyword occurrence, citations by publications, article citations by country, and citations by journal. Fourth, each one of the selected keywords will be analyzed to clarify their origin, evolution, and present definition in relation to Construction 4.0. This approach combines two techniques, as defined by Seuring and Gold [16]: literature review as the primary source of information for qualitative results and a meta-analysis of the statistical findings.

\subsection{Theoretical Framework and Preliminary Analysis}

The term "Construction 4.0" has gained popularity over the last years, and it is present in a myriad of undocumented sources, such as blogs or websites about the construction industry; on the contrary, scientific sources are still scarce. Thus, the first challenge of this review was to find a balance between comprehensiveness and scientific rigor. As part of a preliminary analysis, if the definitions of Construction 4.0 proposed by Roland Berger [2], Sawhney et al. [3], and Craveiro et al. [13] are analyzed together, a common pattern can be recognized. This term is then defined as an umbrella covering several areas and is characterized by keywords that identify emerging trends that have been transferred from Industry 4.0, as shown in Table 1.

Table 1. Emerging trends from Industry 4.0.

\begin{tabular}{|c|c|c|}
\hline Umbrella Concept & Areas & Emerging Trends \\
\hline $\begin{array}{l}\text { Digitization of the } \\
\text { construction industry [2] }\end{array}$ & $\begin{array}{l}\text { Digital data, } \\
\text { Automation, } \\
\text { Connectivity, } \\
\text { Digital access }\end{array}$ & $\begin{array}{l}\text { Analytics/big data in operation and } \\
\text { production, additive manufacturing, } \\
\text { robotics in production, e-commerce, } \\
\text { 4PL, multichannel retail, RFID } \\
\text { marketing, analytics/big data in } \\
\text { marketing, PLM, human-machine } \\
\text { collaboration, analytics/big data in } \\
\text { logistics, digital WMS, augmented } \\
\text { reality in production, M-commerce, } \\
\text { Smart MES, logistics software } \\
\text { management, predictive maintenance, } \\
\text { mobile logistics systems, CRM } \\
\text { systems, cloud-based logistics } \\
\text { solutions, automated digital } \\
\text { marketing, analysis/big data } \\
\text { procurement, buyer-side/seller-side } \\
\text { e-procurement, location-based } \\
\text { marketing, customer service } \\
\text { satisfaction, analytics in customer } \\
\text { service, social media, field service } \\
\text { management, digital content } \\
\text { marketing, m-marketing, digital } \\
\text { storytelling, e-supplier relationship } \\
\text { management, augmented reality in } \\
\text { marketing, e-marketplaces }\end{array}$ \\
\hline
\end{tabular}


Table 1. Cont.

\begin{tabular}{|c|c|c|}
\hline Umbrella Concept & Areas & Emerging Trends \\
\hline $\begin{array}{l}\text { Transformation of the } \\
\text { construction industry towards } \\
\text { the 4th industrial revolution } \\
\text { [13] }\end{array}$ & $\begin{array}{l}\text { Digitization of the } \\
\text { construction industry, } \\
\text { Industrialization of the } \\
\text { construction process }\end{array}$ & $\begin{array}{l}\text { Resources of the future, circular } \\
\text { economy, sensors, building survey, } \\
\text { drones, autonomous vehicles, BIM, } \\
\text { Nanotechnology, advanced materials, } \\
\text { additive manufacturing, robots, } \\
\text { advanced manufacturing systems, big } \\
\text { data, internet of things, cyber security }\end{array}$ \\
\hline Transformative framework [3] & $\begin{array}{l}\text { Industrial production } \\
\text { and construction, } \\
\text { Cyber-physical systems, } \\
\text { Digital technologies }\end{array}$ & $\begin{array}{l}\text { Building Information Modelling } \\
\text { (BIM), CDE, unmanned aerial systems, } \\
\text { cloud-based project management, } \\
\text { Augmented Reality/Virtual reality } \\
\text { (AR/VR), artificial intelligence, } \\
\text { cybersecurity, big data and analytics, } \\
\text { blockchain, laser scanner, robotics and } \\
\text { automation, sensors, IoT, workers } \\
\text { with wearable sensors, actuators, } \\
\text { additive manufacturing, offsite } \\
\text { construction and equipment } \\
\text { with sensors }\end{array}$ \\
\hline
\end{tabular}

As the number of trends is too large, a first tentative classification was made to start the bibliographical analysis based on three seminal authors (Roland Berger [2], Sawhney et al. [3], and Craveiro et al. [13]) who have served as a basis to define the scope of the pillars shown in Figure 1 (digitalization and industrialization) and their related concepts, which characterize the term Construction 4.0 and its relationship with the seven keywords proposed which find specific application in the construction industry (Table 2).

Table 2. Relationship between pillars of Construction 4.0 and the proposed keywords.

\begin{tabular}{|c|c|c|c|c|}
\hline $\begin{array}{c}\text { Craveiro et al. } \\
\text { [13] }\end{array}$ & $\begin{array}{c}\text { Sawhney et al. } \\
{[3]}\end{array}$ & $\begin{array}{c}\text { Roland Berger } \\
{[2]}\end{array}$ & $\begin{array}{l}\text { Proposed } \\
\text { Keywords }\end{array}$ & Emerging Trends \\
\hline \multirow{3}{*}{$\begin{array}{l}\text { Digitization } \\
\text { of the } \\
\text { construction } \\
\text { industry }\end{array}$} & \multirow{3}{*}{$\begin{array}{l}\text { Cyber-physical } \\
\text { systems, } \\
\text { Digital } \\
\text { technologies }\end{array}$} & \multirow{3}{*}{$\begin{array}{l}\text { Digital data, } \\
\text { Automation, } \\
\text { Connectivity, } \\
\text { Digital access }\end{array}$} & $\begin{array}{l}\text { New materials } \\
\text { related to } \\
\text { industrialization }\end{array}$ & $\begin{array}{c}\text { Product life cycle management } \\
\text { (PLM), resources of the future, } \\
\text { circular economy, } \\
\text { nanotechnology, } \\
\text { advanced materials }\end{array}$ \\
\hline & & & 3D printing & $\begin{array}{l}\text { Additive manufacturing, } \\
\text { Smart Manufacturing } \\
\text { execution system (MES), } \\
\text { additive manufacturing, } \\
\text { advanced } \\
\text { manufacturing systems }\end{array}$ \\
\hline & & & $\begin{array}{l}\text { Internet of Things } \\
\text { (IoT) }\end{array}$ & $\begin{array}{l}\text { Field service management, } \\
\text { sensors, building survey, } \\
\text { drones, autonomous vehicles, } \\
\text { unmanned aerial systems, } \\
\text { laser scanner, actuators }\end{array}$ \\
\hline
\end{tabular}


Table 2. Cont.

\begin{tabular}{|c|c|c|c|c|}
\hline $\begin{array}{c}\text { Craveiro et al. } \\
{[13]}\end{array}$ & $\begin{array}{l}\text { Sawhney et al. } \\
{[3]}\end{array}$ & $\begin{array}{c}\text { Roland Berger } \\
{[2]}\end{array}$ & $\begin{array}{l}\text { Proposed } \\
\text { Keywords }\end{array}$ & Emerging Trends \\
\hline \multirow{4}{*}{$\begin{array}{l}\text { Industrialization } \\
\text { of the } \\
\text { construction } \\
\text { process }\end{array}$} & \multirow{4}{*}{$\begin{array}{l}\text { Industrial } \\
\text { production and } \\
\text { construction }\end{array}$} & & $\begin{array}{l}\text { Artificial } \\
\text { intelligence and } \\
\text { robotics }\end{array}$ & $\begin{array}{l}\text { Robotics in production, } \\
\text { human-machine collaboration, } \\
\text { robots, robotics and } \\
\text { automation, workers with } \\
\text { wearable sensors, offsite } \\
\text { construction and equipment } \\
\text { with sensors }\end{array}$ \\
\hline & & & $\begin{array}{l}\text { Computer-aided } \\
\text { design } \\
\text { technologies (BIM) }\end{array}$ & $\begin{array}{c}\text { Predictive maintenance, } \\
\text { Building Information } \\
\text { Modelling (BIM), } \\
\text { Collaborative development } \\
\text { environment (CDE), } \\
\text { cloud-based } \\
\text { project management }\end{array}$ \\
\hline & & & Big data & $\begin{array}{c}\text { Analytics/big data in operation } \\
\text { and production, e-commerce, } \\
\text { 4PL, multichannel retail, RFID } \\
\text { marketing, analytics/big data } \\
\text { in marketing, analytics/big } \\
\text { data in logistics, digital } \\
\text { warehouse management } \\
\text { system (WMS), M-commerce, } \\
\text { logistics software } \\
\text { management, mobile logistics } \\
\text { systems, Customer } \\
\text { relationship management } \\
\text { (CRM) systems, cloud-based } \\
\text { logistics solutions, automated } \\
\text { digital marketing, analysis/big } \\
\text { data procurement, } \\
\text { buyer-side/seller-side } \\
\text { e-procurement, location-based } \\
\text { marketing, customer service } \\
\text { satisfaction, analytics in } \\
\text { customer service, social media, } \\
\text { digital content marketing, } \\
\text { m-marketing, digital } \\
\text { storytelling, e-supplier } \\
\text { relationship management, } \\
\text { e-marketplaces, cyber } \\
\text { security, blockchain }\end{array}$ \\
\hline & & & $\begin{array}{l}\text { Virtual and } \\
\text { augmented reality }\end{array}$ & $\begin{array}{l}\text { Augmented reality in } \\
\text { production, augmented reality } \\
\text { in marketing Augmented } \\
\text { Reality/Virtual reality (AR/VR) }\end{array}$ \\
\hline
\end{tabular}

In the case that some of the emerging trends matched exactly with one of the seven proposed keywords, they were eliminated. These seven keywords were then hypothesized to be representative of the definition of the term Construction 4.0 and, therefore, were used to conduct the corresponding bibliographical review.

\subsection{Literature Review}

Based on the seven keywords proposed in Table 2, two types of literature searches were conducted. In the first search, the seven keywords were used together with the term "Construction 4.0", while in the second search, they were combined with the Boolean operation "Industry 4.0" AND "Construction". Both literature searches were done among WoS/ISI scientific journals, considering the following limitations: 
(i) Research articles, reports, and conference proceedings were included;

(ii) The search looked for words in the title, abstract and keywords of the articles;

(iii) The search was restricted to English language only. However, in the case that other languages are used but at least the title, the abstract, and the keywords were in English, the document was considered valid;

(iv) The temporal span was delimited to 2014-2019, in accordance with the considerations made in the Section 1. Additionally, when a publication was found to comply with those criteria, its keywords were also screened to check whether they bear relationship with those from other selected articles. Once the data was available, the following analysis was conducted to clarify the most relevant trends.

After this, a bibliometric analysis was conducted to clarify deeper relations between the selected publications. This type of analysis is frequently applied to literature reviews, since it serves to visualize large amounts of data through graphs. Mathematical and statistical methods are used to analyze these relationships.

Through the Web of Science platform (WoS/ISI), a record of the most relevant data of the publications in this review was obtained. These data were processed in VOSviewer ${ }^{\mathrm{TM}}$, a program that constructs and visualizes bibliometric maps developed by The University of Leiden. For this study, 4 kinds of analysis were created: (i) keyword cooccurrence, to clarify which are the most shared keywords by the selected publications; (ii) number of citations by publications, to clarify which are the key publications that are most cited by authors in this field; (iii) number of citations of publications by country, to clarify which are the leading countries regarding publications in this field; and (iv) number of citations by journal, to clarify which journals cluster the highest number of citations regarding Construction 4.0 .

\section{Results and Data Analysis}

For preparation of this literature review, a total of 86 scientific journals were examined, all of which are indexed in the $2019 \mathrm{WoS} / \mathrm{ISI}$ journal list and were published from 2014 onwards. Thus, a total of 257 articles were collected that met all the aforementioned requirements to be part of this review. Next, quantitative and bibliographic analyses were carried out on the information.

\subsection{Quantitative Analysis}

A search was carried out in the WoS/ISI database, using combinations of the seven proposed keywords and the term Construction 4.0 and considering the limitations that were mentioned. From this search, 257 articles were found, which were distributed amongst 86 scientific journals, giving as an average around 3 articles per journal. Since this number was too high, the 10 journals with the largest number of publications were then selected, accounting all together for 129 articles (representing $50.2 \%$ of the total). This allowed for clarification of the most influential journals on these topics (as shown in Table 3) and provides a useful source of information that optimizes the researcher's time and works. 
Table 3. Articles selected by journal.

\begin{tabular}{cc}
\hline Journal & Number of Articles \\
\hline Automation in Construction & 54 \\
Future Generation Computer Systems & 18 \\
Construction and Building Materials & 10 \\
Journal of Cleaner Production & 10 \\
Computer Networks & 9 \\
Business Horizons & 7 \\
Technological Forecasting and Social Change & 7 \\
Computers in Industry & 6 \\
Journal of Network and Computer Applications & 4 \\
International Journal of Information Management & 4 \\
\hline
\end{tabular}

In the information obtained from the journals with the most selected publications, it can be seen that $63 \%$ of the publications for the literature review are from the journal Automation in Construction, for which the scope, as mentioned previously, is strongly related to topics under study. This is an international research publication that focuses on engineering, design, technology, maintenance, and management-oriented to buildings and information. Also, it has an impact factor of 4.313 (2019 journal citation reports) and a 5-year impact factor of 5276 (2019 journal citation reports). Consequently, it is to be expected that most articles were selected from this journal as it covers topics that are similar to those required for the literature review.

An additional analysis was conducted to clarify some aspects of Table 3. The objective was to clarify which journals publish research on each topic, which will show which are influential for a concrete area, in contrast with the global influence that was showed by Table 3 (see Table 4). It is remarkable that, for all seven considered keywords, around $25-40 \%$ of the publications on a single topic are present in the top ten, except for artificial intelligence and robotics, and new materials related to industrialization (with 15\% each). This suggests that research in each area is somewhat related to the others, but in the case of artificial intelligence and robotics, that may not be the case, with the knowledge more dispersed across several publications.

Table 4. Journals selected according to relevance and relationship with Construction 4.0.

\begin{tabular}{cc}
\hline Topics & Journals \\
\hline Business and Information Systems Engineering \\
Business Horizons \\
Computer Communications \\
Computer Networks \\
Computers and Electrical Engineering \\
Computers in Industry \\
Internet of Things \\
(Number of journals: 19) \\
(Journals in the top ten: 6) \\
IEEE Access \\
IEEE Communications Survey and Tutorials \\
IEEE Internet of Things Journal \\
IEEE Transactions on Industrial Informatics \\
International Journal of Digital Earth \\
International Journal of Research in Marketing \\
Journal of Cleaner Production \\
Journal of Network and Computer Applications \\
Sustainable Cities and Society \\
Technological Forecasting and Social Change \\
Telecommunication Systems \\
The International Journal of Advanced \\
Manufacturing Technology
\end{tabular}


Table 4. Cont.

\begin{tabular}{|c|c|}
\hline Topics & Journals \\
\hline $\begin{array}{l}\text { Technologies in computer-aided design } \\
\text { (BIM) } \\
\text { (Number of journals: 11) } \\
\text { (Journals in the top ten: 3) }\end{array}$ & $\begin{array}{c}\text { Advanced Engineering Informatics } \\
\text { Advanced in Engineering Software } \\
\text { Applied Energy } \\
\text { Automation in Construction } \\
\text { Energy } \\
\text { Energy and Buildings } \\
\text { International Journal of Project Management } \\
\text { Journal of Cleaner Production } \\
\text { Journal of Management in Engineering } \\
\text { Safety Science } \\
\text { Technological and Economic Development of Economy }\end{array}$ \\
\hline $\begin{array}{l}\text { 3D printing } \\
\text { (Number of journals: } 16) \\
\text { (Journals in the top ten: } 4 \text { ) }\end{array}$ & $\begin{array}{c}\text { Advanced Materials } \\
\text { Archives of Civil and Mechanical Engineering } \\
\text { Automation in Construction } \\
\text { Business Horizons } \\
\text { Cement and Concrete Composites } \\
\text { Cement and Concrete Research } \\
\text { Construction and Building Materials } \\
\text { Energy Policy } \\
\text { Engineering with Computers } \\
\text { International Journal of Production Economics } \\
\text { JOM } \\
\text { Journal of Engineering and Technology Management } \\
\text { Materials and Design } \\
\text { Materials and Structures } \\
\text { Microsystem Technologies } \\
\text { Technological Forecasting and Social Change }\end{array}$ \\
\hline $\begin{array}{c}\text { Big Data } \\
\text { (Number of journals: } 16) \\
\text { (Journals in the top ten: } 6 \text { ) }\end{array}$ & $\begin{array}{c}\text { Academy of Management Journal } \\
\text { Advanced Engineering Informatics } \\
\text { Applied Energy } \\
\text { Business Horizons } \\
\text { Economic Inquiry } \\
\text { Future Generation Computer Systems } \\
\text { IEEE Access } \\
\text { Information Fusion } \\
\text { Information Systems } \\
\text { International Journal of Digital Earth } \\
\text { International Journal of Information Management } \\
\text { International Journal of Production Economics } \\
\text { Journal of Business Research } \\
\text { Journal of Cleaner Production } \\
\text { Journal of Parallel and Distributed Computing } \\
\text { Mobile Networks and Applications }\end{array}$ \\
\hline
\end{tabular}


Table 4. Cont.

\begin{tabular}{|c|c|}
\hline Topics & Journals \\
\hline $\begin{array}{l}\text { Artificial intelligence and robotics } \\
\text { (Number of journals: } 20 \text { ) } \\
\text { (Journals in the top ten: } 3 \text { ) }\end{array}$ & $\begin{array}{c}\text { Ad Hoc Networks } \\
\text { Automation in Construction } \\
\text { Business Horizons } \\
\text { Cement and Concrete Research } \\
\text { Cognitive Systems Research } \\
\text { Computers in Human Behavior } \\
\text { Energy and Buildings } \\
\text { Engineering Structures } \\
\text { Computer-Aided Civil and Infrastructure Engineering } \\
\text { Frontiers of Information Technology and Electronic Engineering } \\
\text { Future Generation Computer Systems } \\
\text { IEEE Transactions on Automation Science and Engineering } \\
\text { IEEE Wireless Communications } \\
\text { Journal of Computing in Civil Engineering } \\
\text { Journal of Infrastructure Systems } \\
\text { Journal of Service Research } \\
\text { Mechatronics } \\
\text { Mobile Networks and Applications } \\
\text { Progress in Aerospace Science } \\
\text { Robotics and Computer-Integrated Manufacturing }\end{array}$ \\
\hline $\begin{array}{l}\text { Virtual and augmented reality } \\
\text { (Number of journals: 11) } \\
\text { (Journals in the top ten: } 4 \text { ) }\end{array}$ & $\begin{array}{c}\text { Advanced Engineering Informatics } \\
\text { Automation in Construction } \\
\text { British Journal of Psychology } \\
\text { Computers in Human Behavior } \\
\text { Computers in Industry } \\
\text { Future Generation Computer Systems } \\
\text { Interactive Learning Environments } \\
\text { Journal of Computing in Civil Engineering } \\
\text { Journal of Construction Engineering and Management } \\
\text { Surgical Endoscopy } \\
\text { Virtual Reality }\end{array}$ \\
\hline $\begin{array}{l}\text { New materials related to industrialization } \\
\text { (Number of journals: 13) } \\
\text { (Journals in the top ten: } 2 \text { ) }\end{array}$ & $\begin{array}{c}\text { Bioresource Technology } \\
\text { Carbon } \\
\text { Ceramic International } \\
\text { Energy } \\
\text { Construction and Building Materials } \\
\text { International Journal of Hydrogen Energy } \\
\text { International Journal of Impact Engineering } \\
\text { Journal of Cleaner Production } \\
\text { Materials and Structures } \\
\text { Nano Energy } \\
\text { Renewable and Sustainable Energy Reviews } \\
\text { Renewable Energy } \\
\text { Safety Science }\end{array}$ \\
\hline
\end{tabular}

After this, the publications were sorted per year and keywords, as shown in Figure 2, where it is clear that, since 2014, there is an increasing number of publications, which seems to be growing exponentially, evidencing the increasing interest of researchers in those topics. It may be hypothesized that this trend also shows that the topics greatly contribute to the development of the construction industry worldwide as they find application in a variety of fields within it. Therefore, it seems that the necessity for more efficient processes and forms of work motivates these types of studies. 


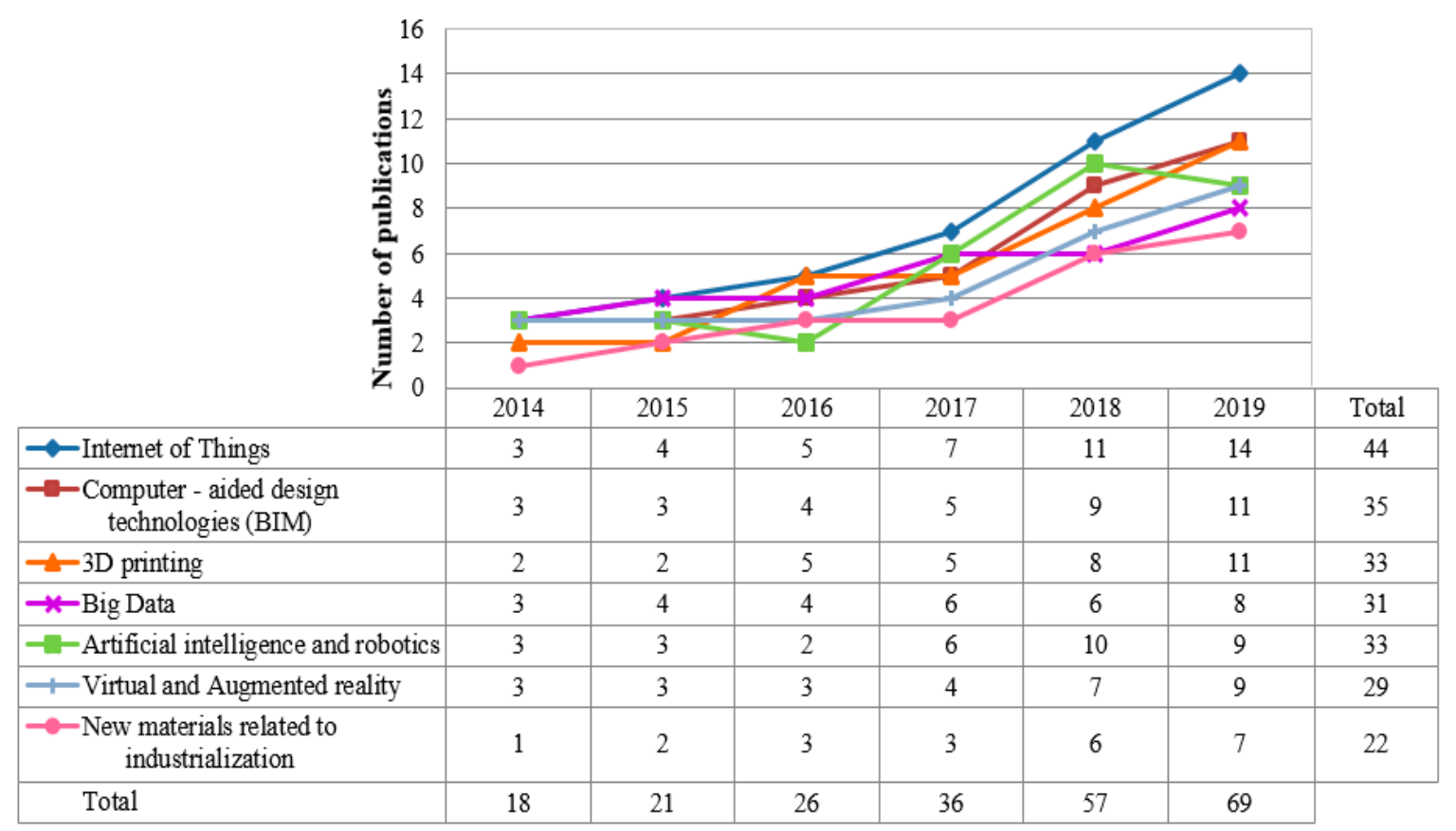

Figure 2. Publications by topic and year.

An increase of 51 publications was observed from 2014 to 2019, which translates into a 283\% growth in the number of documents. This is evidence of a strong trend of increasing research in the areas that comprise Construction 4.0, thereby demonstrating a marked interest in investigating these subjects on the part of authors. In addition, Internet of Things was identified as the Construction 4.0 area with the most publications selected for literature review, with $19.4 \%$ more documents than the other areas. This can be interpreted as a greater interest in knowledge of and conducting further research on this technology because of its impact and its projected future development and expansion. Due to its versatility, which can range from work-related to everyday applications, this topic gives rise to an extensive number of publications because its research possibilities are quite broad.

Finally, each keyword was related to the publications that mention them, which allows, together with the list of references, to identify authors publishing on each topic. This will also help scholars in finding authors for concrete areas of research related to Construction 4.0 (Table 5). The 20 most cited authors out of around 1000 are depicted for each category, covering 227 publications out of 257; that is, $2 \%$ of the authors are covering $83.3 \%$ of the publications considered in this review.

\subsection{Bibliometric Analysis}

According to the previous analysis, there is a vast base of data with information related to the topics that make up Construction 4.0: Internet of Things, computer-aided design technologies (BIM), 3D printing, big data, artificial intelligence and robotics, virtual and augmented reality, and new materials related to industrialization. In fact, due to the large number of publications, it is difficult to analyze all the available information, and if that is done, only partial conclusions can be obtained. Furthermore, a limited number of publications specifically focus on Construction 4.0 and do not entirely focus on the advancement of this concept in engineering.

There is limited evidence of the existence of an overview or general perspective focused on Construction 4.0 or recent research and publications on the subject. Therefore, it is necessary to gather all this available information to analyze and synthesize it for future scientific research and to deliver a broader vision of Construction 4.0 based on an updated state of the research on the topic, including the new findings and the key concepts that have characterized this industry in recent years. 
Table 5. Relationship between authors and areas of Construction 4.0.

\begin{tabular}{|c|c|c|c|c|c|c|c|c|c|c|c|c|c|c|}
\hline \begin{tabular}{|ll} 
Areas of Construction 4.0 & Authors Cited \\
\end{tabular} & [17-27] & $\begin{array}{c}{[15,28-} \\
30]\end{array}$ & $\begin{array}{r}{[7,11,} \\
31-37] \\
\end{array}$ & [38-45] & {$[46-51]$} & $\begin{array}{c}{[1,46,47,} \\
52-58]\end{array}$ & [59-66] & {$[67-75]$} & [76-82] & [83-85] & {$[86,87]$} & [88-90] & {$[91]$} & [92] \\
\hline Internet of Things & & & & $\bullet$ & $\bullet$ & $\bullet$ & & & & & & $\bullet$ & & \\
\hline $\begin{array}{l}\text { Computer-aided design technologies } \\
\text { (BIM) }\end{array}$ & $\bullet$ & $\bullet$ & & & & & & & & & & & & $\bullet$ \\
\hline $3 \mathrm{D}$ printing & & & & & & & $\bullet$ & $\bullet$ & & & $\bullet$ & $\bullet$ & & $\bullet$ \\
\hline Big Data & & & $\bullet$ & $\bullet$ & $\bullet$ & $\bullet$ & $\bullet$ & & & & & $\bullet$ & & \\
\hline Artificial intelligence and robotics & & & $\bullet$ & $\bullet$ & $\bullet$ & & & & & & $\bullet$ & & $\bullet$ & \\
\hline Virtual and augmented reality & $\bullet$ & $\bullet$ & & & & & & & $\bullet$ & & & & $\bullet$ & \\
\hline $\begin{array}{l}\text { New materials related to } \\
\text { industrialization }\end{array}$ & & & & & & & & & & $\bullet$ & & & & \\
\hline
\end{tabular}


For that reason, the second stage of this literature review aimed at unveiling unique and hidden connections between different aspects of these concepts that could not be clarified with the previous analysis. For that purpose, the application VOSviewer ${ }^{\mathrm{TM}}$ was used. This software reads bibliographical information from data downloaded from scientific databases (WoS/ISI in this case) and performs different kinds of analysis, revealing connections and presenting the information in a graphical way. Amongst the variety of options that the interface offers, two visualizations were chosen for this analysis: network visualization and density visualization. In the first one, concepts are represented by circles, which are linked by straight lines. The circle size shows the relative weight of the element in the analysis; some circles share the same color, which means that they form a cluster, that is, those concepts are shared by a publication. The lines depict the relation between concepts in the form of co-citations: the shorter the line, the more co-citations exist between those concepts. In the second one, concepts are represented by labels; items cluster around those labels and, the more items, the hotter the color (yellow, orange, or red); and related concepts are placed close to another, so that they can also form clusters.

Some parameters can be modified to obtain more accurate and meaningful maps, such as the minimum number of co-citations, documents, or occurrence of keywords to clean the map and to eliminate results that are not relevant.

\subsubsection{Analysis of Keyword Cooccurrence}

The first analysis was based on the cooccurrence of keywords. A minimum number of 2 cooccurring keywords was established in order to filter and obtain more representative results. Based on the data set containing 257 publications and using the keywords determined by the author of each publication, a total of 880 keywords were identified. Of these, 103 meet the previously set minimum cooccurrence number requirement and are connected by 298 links, which show the relationship between concepts (Figure 3).

Internet of Things and big data seem to be the most used keywords ( 36 and 28 cooccurrences, respectively), although they are not part of the most influential cluster, which are the red and the green ones, with 14 and 12 elements, respectively. On top of that, Internet of Things and big data were the terms with more cooccurrences. It was also observed that both are directly connected in the same cluster and have a large number of links with other terms, 14 and 12, respectively. That is, Internet of Things connects with $14 \%$ of a total of 103 keywords, and big data connects with $12 \%$. Three-dimensional printing and additive manufacturing are very close, and the former nearly equals IoT or big data in weight, although this cluster seems so be far from the most influential one.

It can be highlighted that, despite some keywords being used in many occasions, they do not share a cluster with other ones. Not only the most cited but also the most interconnected keywords could be identified.

It can be seen that some areas of Construction 4.0 are related to each other. For example, the Internet of Things has a strong relationship with big data, and augmented reality is related to BIM. This suggests a connection between areas, which implies that they can work and be applied together to achieve a common goal. In the same context, it is possible to observe the relationship between the areas under study and their applications. Furthermore, it seems clear that a connection exists between Industry 4.0 and the construction industry, which were previously shown to be the basis of Construction 4.0. This reflects the perspective of this literature review and confirms the connection between Construction 4.0's areas based on the proximity of the elements and their links. 


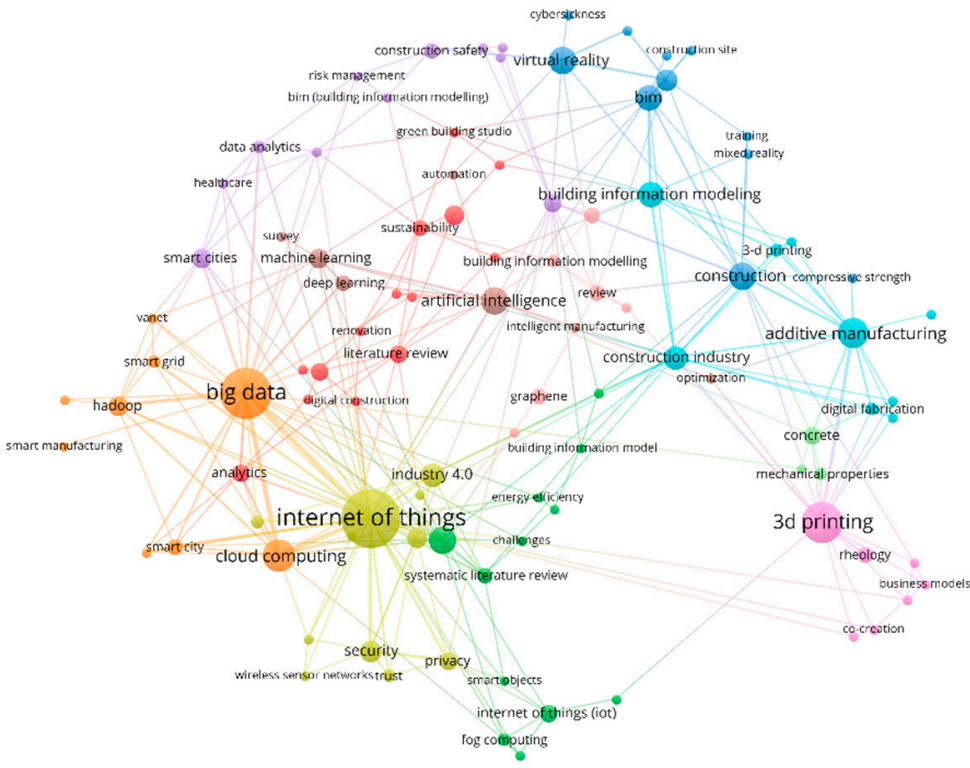

sosviewer

Figure 3. Map of cooccurrence of author-selected keywords.

\subsubsection{Analysis of the Number of Publication Citations}

The second analysis presents the number of times the publications were cited by other authors. The minimum number of citations for the documents was set at 5 to ascertain which articles have the greatest influence on the literature review. Accordingly, out of a total of 257 publications, 194 are cited 5 or more times by other authors, of which 109 are connected to each other (Figure 4).

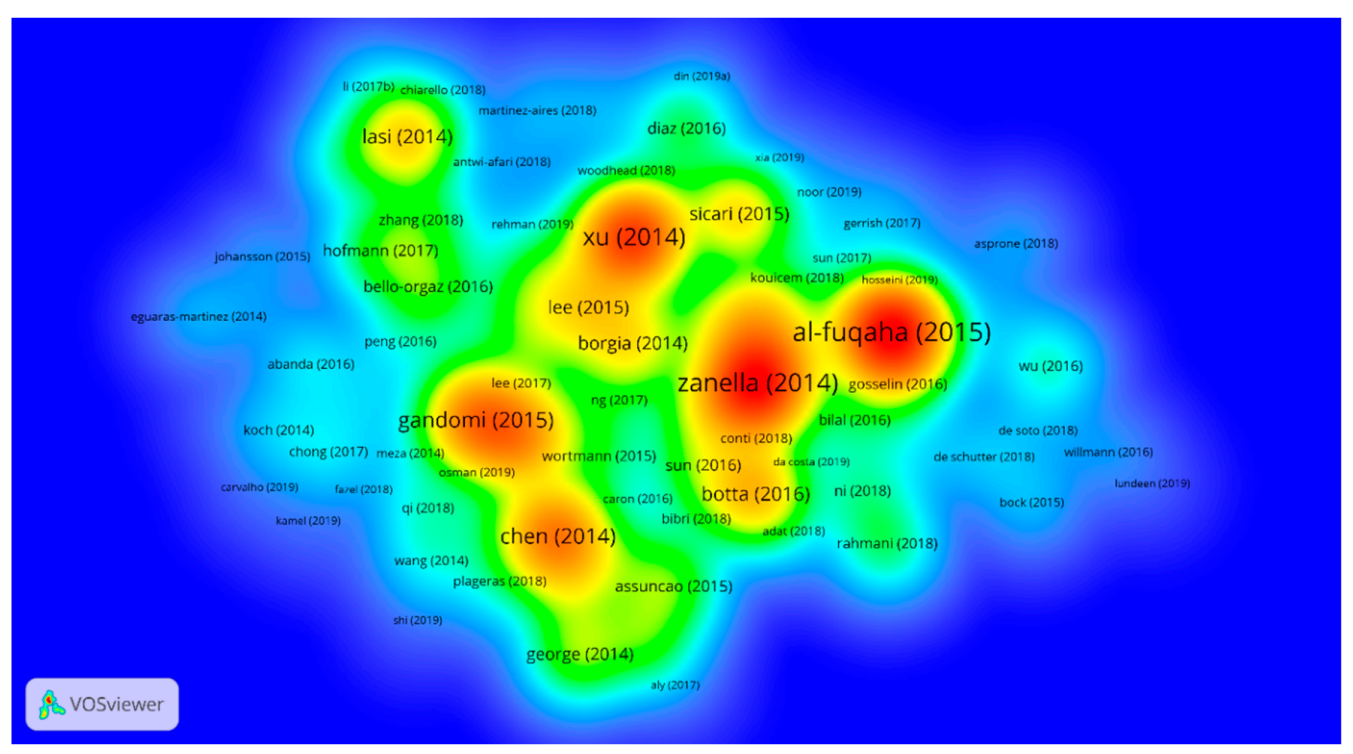

Figure 4. The most influential publications in the literature review (density visualization).

With approximately 1000 references, the publications in the red zones have been the most influential and provide valuable information for the literature review. These publications are oriented toward research related to the Internet of Things and primarily its applications both in everyday life and in the industry. As such, it can be deduced that this topic is currently one of the most influential. This is related to the previous analysis, since this area reappears as one of those that generate the greatest scientific impact through the citations in subsequent publications. It is important to highlight 
that, although the number of times a publication is cited indicates its visibility or impact, this is not a clear indicator of scientific quality, even though there might be a positive correlation between the number of citations and scientific quality.

\subsubsection{Analysis of Article Citations by Country}

The third analysis focuses on the number of publication citations according to the country of origin. This provides an overview of the countries where Construction 4.0's areas are in development. It was found that the 257 selected publications come from 52 countries. Therefore, a minimum number of 2 document citations were established to determine the most influential countries in the progress of Construction 4.0.

It was found that a total of 41 countries fulfilled the minimum number of publications requirement, as described in Figure 5.

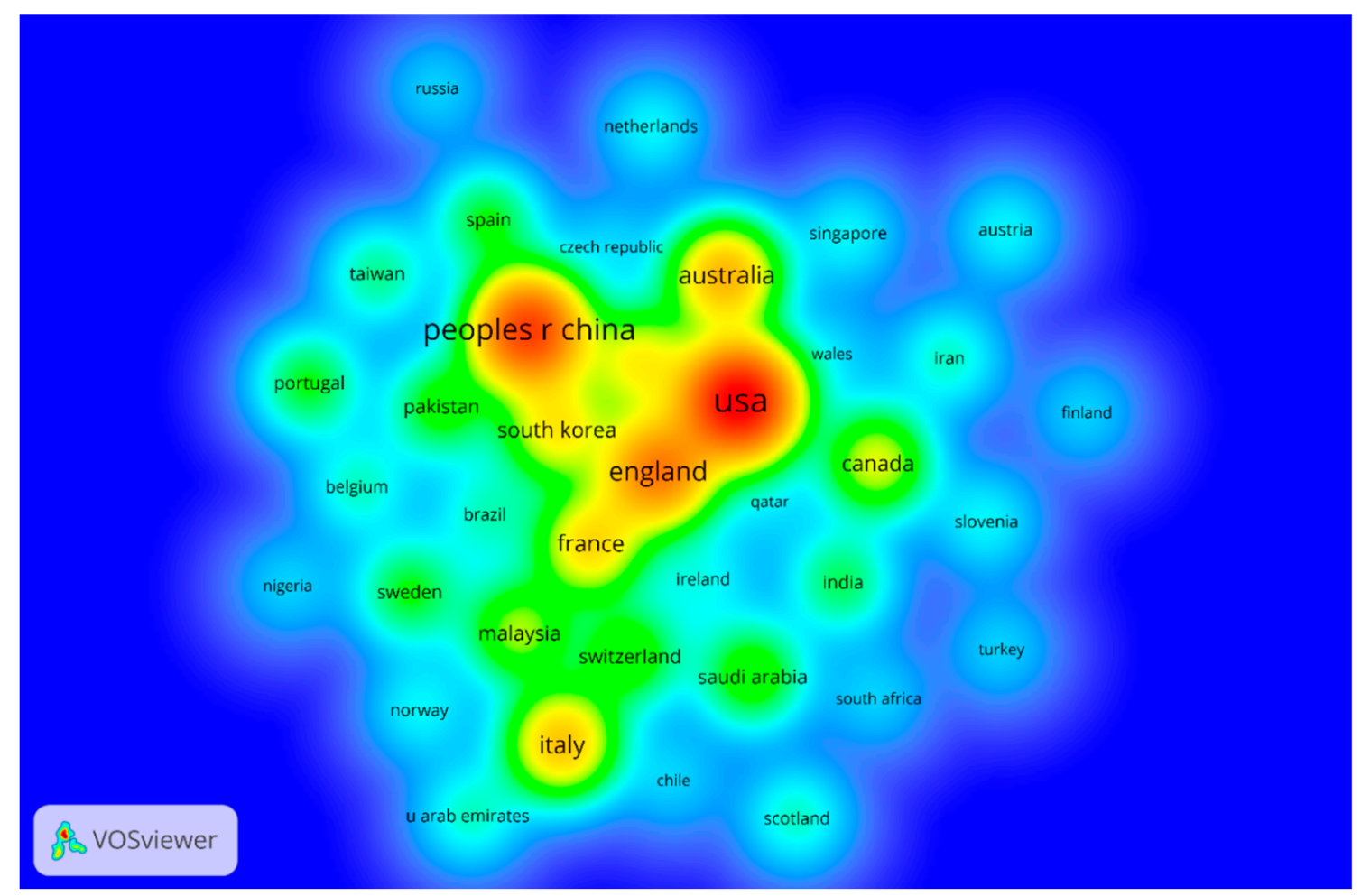

Figure 5. Countries with the most documents cited (density visualization).

For analysis of the number of publication citations, of a total of 257 documents, 194 are cited 5 or more times by other authors, which represents $75 \%$ of the literature review publications. About the third bibliometric analysis, it was found that $23 \%$ of the publications are from the USA; in other words, almost a quarter of the research comes from this country. The last analysis focused on the number of journal citations that are part of the literature review. Out of a total of 86 journals, 34 are cited more than 2 times. This is equivalent to $40 \%$ of the total, thus revealing that most of journals considered have a high number of citations.

It is clear that the USA is one of the most influential countries in the sense that a greater number of publication citations come from that country. A total of 60 documents selected for this review were cited 9211 times in articles from the United States, which means that a large part of the development of the areas that make up Construction 4.0 is concentrated here.

Additionally, it can be observed that most of the countries where these technologies have progressed are developed countries in Europe plus South Korea and Australia. This is a very important indicator because it demonstrates that these countries have the resources to produce a 
great deal of scientific research and publications. This coincides with Construction 4.0's objectives, since, through new technologies and processes, it seeks to increase the productivity and economic efficiency of the construction industry. However, China should also be regarded as an economy in rapid transformation that has found its place in this landscape. The triad of USA-China-England dominates this field, with other countries orbiting around them.

\subsubsection{Analysis of Citations by Journal}

The fourth analysis shows the number of citations per journal, which allows to clarity two aspects: first, which journals are gathering relevant information on these topics and, second, how these journals cluster, that is, how they relate to each other. These aspects are relevant to our study because publications are allocated to journals depending primarily on their scope. Similar to the previous analyses (Figure 5), a minimum number of 2 citations of a scientific article as well as a minimum of 1 document from a single article was established to filter the information and to obtain relevant data. Out of a total of 86 journals, 34 comply with the minimum number of documents. These results were then refined to only 30 journals connected between themselves, as shown in Figure 6.

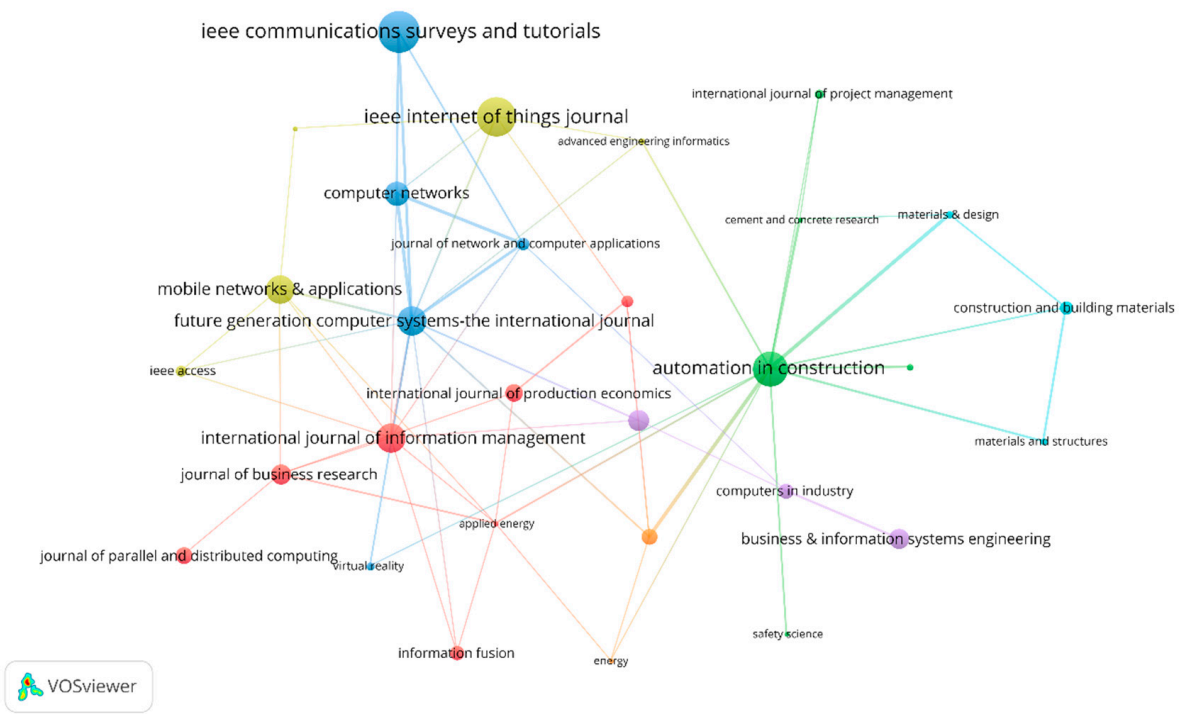

Figure 6. Citations by journal.

It is evident that the 3 journals with the most citations in descending order are IEEE Communications Surveys and Tutorials, IEEE Internet of Things Journal, and Automation in Construction. These journals are also prominent as heads of their respective clusters; the most cited focuses mainly on developments related to the Internet of Things. Also, these journals are connected to others with similar topics, that is, those focusing on technological advancements in computer networks.

After, 3 journals can be also highlighted as heads of secondary clusters: IEEE Transactions on Industrial Informatics, Mobile Network and Applications, and Information Sciences; these three seem to be related more with information than with construction itself and are quite close to each other, suggesting proximity in their scope.

\section{Discussion of Key Concepts in Relation to Construction 4.0: Definitions, Trends, and Challenges}

This study aimed to establish a theoretical framework for the concept Construction 4.0, for which the definition, as pointed out by previous authors, is still in constant evolution and is influenced by its parent concept Industry 4.0. For that purpose, a tentative list of keywords was proposed based on previous studies and used to guide and conduct a literature review for publications over the period 2014-2019. 
The results show that these seven key concepts can be considered relevant to describe the present state of affairs of Construction 4.0. The relation between authors, publications, concepts, journals, and countries has provided new information that will help in proposing a tailored and accurate definition for this emerging area.

In this sense, it was deemed necessary to include an additional discussion about each one of these seven concepts in order to clarify their origin, evolution, present definition, and how can they help in building this theoretical framework for Construction 4.0. Each of them is analyzed in the following subsections, together with the most relevant bibliometric trends.

\subsection{Internet of Things}

The concept "Internet of Things" (IoT) [38] was created in 1999 at the Massachusetts Institute of Technology (MIT). It is recognized as one of the most important areas of future technology and is receiving a great deal of attention from industries [93]. It can be defined as a global network of machines capable of communication and making it possible for objects to share information and to then make decisions, which converts them into smart objects through the use of technology to achieve a common goal [38,93]. Additionally, they can process data in real-time, where network congestion has decreased as wireless networks have increased their speed, providing optimal connectivity [49]. Larger amounts of shared information together with networks with improved capacity show that this area is subject to continuous innovation [52,94].

In relation to Construction 4.0, five IoT technologies used for the implementation of products and services based on successful IoT were identified [49,93]: radio-frequency identification (RFID), wireless sensor networks (WSNs), middleware, cloud computing, and IoT application software.

IoT is also used in conjunction with the "cloud" for real-time data transmission for monitoring systems $[48,53]$. In this sense, not only in the design and construction phase but also during the operation of buildings, IoT is changing the way that users interact with their homes. An example of this is the concept of a smart home, in which the user can control a large number of devices to simplify daily life completely remotely through an intelligent network [54]. IoT can also be used in a broader scale in urban planning: the so-called "smart city" aims to optimize distribution networks and public services by managing large amounts of data in real-time, bringing positive impacts to the lives of their citizens $[40-42,55]$.

However, IoT must face challenges, which are mainly related to security and privacy $[56,57,95]$; this remains specially important during the operational phase of buildings, when private information from users must be handled carefully. One of the main concerns is related to the privacy of information coming from the so-called "smart homes", which integrate IoT in a variety of home devices, especially those related to disaster information, healthcare [43], or energy management [58], with the challenge of handling large amounts of data transmitted over the Internet to avoid communication problems between devices $[50,51]$. Some reviews have pointed out that privacy in smart homes is one of the main concerns about IoT and has a great impact on intelligent buildings and intelligent manufacturing. Despite the integration of IoT in the design, construction, and operation of smart homes appears to be an added value and to attract investment and clients, the integration of such technologies in construction and the concerns about privacy remains a crucial challenge.

\subsection{Computer-Aided Design Technologies (BIM)}

Computer-aided design technologies emerged around the 1980s [28], and since then, Building Information Modeling (BIM) emerged as a collaborative building design methodology that digitally simulates a project in real-time, integrating all processes and facilitating flow between designers and manufacturers. In this context, BIM has been crucial in digitalization of the construction industry [23-25] and its transition to a 4.0 model, where some examples are found in the integration of an augmented reality model [17,29]: the simulation of energy consumption before the actual operation of the building $[17,18,20,22,29]$ or a more efficient flow of information during the construction 
process $[20,96]$. So far, BIM has been widely implemented in new construction projects, although some authors point out the necessity of fostering the application of this methodology to existing buildings [97], something called "BIMization".

The main challenge that BIM faces is related to the full implementation of this technology in all phases of the design, construction, and operation of buildings [26]. In this context, some studies have pointed out that BIM has had only limited application, not encompassing the projects as a fully integrated digital model, as a tool for cost management and cost estimation [27]. Another crucial challenge is related to the technological limitations when implementing full real-time BIM models during construction, simulating all processes before they actually take place in the real world [19].

\subsection{D Printing (Additive Manufacturing)}

Three-dimensional printing, also known as additive manufacturing, consists of the creation of physical objects through the deposition of layers using a digital plan [92]. When this technology appeared around 1980, it was initially only considered for use in prototyping [67]. Since then, different processes have been developed with different techniques and materials [86,98]. A rapid increase in the use of 3D printing has been identified since the end of 2000, thanks to a rise in sales of relatively affordable 3D printers.

According to diverse authors, 3D printing will have a transformative and positive impact on Construction 4.0, allowing for innovative technologies such as 3D online printing or construction with innovative materials, such as ultra-reinforced concrete or plastic; other authors forecast a favorable implementation of this technology for the year 2030 [69].

Recently, this technology has generated interest in the Construction 4.0 industry, especially with concrete $[68,70,99]$, mainly because it can replace human labor with automatized production, thus allowing for significant reductions in time and for customized and flexible production of buildings [71]. The quality of the printing, the behavior of the materials, the speed, and printing time between layers greatly influence the final result [72].

Regarding its relationship with Construction 4.0, several challenges arise for 3D-printed buildings. This technology still faces several technical limitations that restrict its application to prototypes and scale models. Concrete is one of the materials that best fit 3D-printed construction, but it must be adapted into high-quality and printable materials [73]; large-scale models are still unfeasible due to the limitations of commercially available 3D printers [71]. To overcome these issues, some authors have devised strategies to better implement this technology in their processes. A key study by Oropallo and Pieg1 [74] sets forth ten challenges for 3D printing: shape optimization, design for 3D printing, pre and postprocessing, printing methodologies, error control, multi-material printing, hardware and maintenance issues, part orientation, slicing, and speed.

\subsection{Big Data}

The term big data is relatively recent, as it became widespread in the year 2011 [59]. It is defined as a great volume of data that is difficult to store, process, and analyze in real-time with traditional technologies [44]. These data, which include texts, geometrics, images, videos, sounds, and combinations of these [60], are processed to obtain valuable information [75].

About data storage, analysis is performed according to three main indicators: volume, speed, and variety. This is because traditional physical storage is questionable and inefficient, although the veracity and the value or benefit of the data have also been added as indicators [45].

Big data is present in engineering in industrial and operational processes. Logically, as the amount of information is considerably large, some authors have pointed out the necessity of developing computational techniques to define patterns that optimize information flow [61].

In relation to Construction 4.0, big data is used mainly in urban planning and management, where large quantities of data are utilized to measure, for example, the impact of social variables in urban growth; meanwhile, it is also used for "smart cities" to improve the quality of life for 
inhabitants [100]. A key study on this matter points out that big data, together with the Internet of Things, will bring an exponential increase of heterogeneous information in the construction industry [101] and identifies the main challenges ahead: data security and privacy, data quality, cost implications, and internet connectivity [62]. Due to the large amount of data present, analysis [63] and therefore the application of big data in traditional methods [64] are still complicated. Security is another essential challenge; information can be misused, and confidentiality can be breached [65]. It is also important to develop good information management, where expanding the capabilities of big data requires large investments to be able to carry out correct analyses, which can mean economic risk. On the other hand, one of the biggest challenges is to differentiate which are the most valuable and relevant data; however, although big data is a very innovative technology, research that focuses on its value is still scarce [66].

\subsection{Artificial Intelligence and Robotics}

\subsubsection{Artificial Intelligence}

Artificial intelligence (AI) is primarily the ability to empower machines and systems with intelligence similar to that of humans [89]. Therefore, it is considered a great source of innovation; however, in seeking such similarity, there is the opportunity to counteract the major labor shortage [36].

In the field of Construction 4.0, AI can be applied in artificial vision systems, which allow identification of certain elements in a construction site, and in speech and pattern recognition in order to control in real-time the performance of construction workers [35]. Research is also underway on whether it can predict several phenomena related to the design, construction, and operation of buildings. Besides, one fairly promising application is intelligent manufacturing [37].

The interaction between humans and computers in the construction site brings other pressing challenges for this technology: modeling of human language by computers and the intuition to solve problems or to make decisions, which is still difficult for AI in some areas [91].

\subsubsection{Robotics}

Since 1980, robotics has been implemented for the development of construction projects, and from that time on, these automated projects have been on the rise. Robots stand out for their great precision, speed, and efficiency in a variety of tasks and, when implemented in automated systems, for their increased productivity $[31,32,88]$.

In the construction industry, robotics has adapted to provide solutions to problems, from planning routes for transporting materials to automated systems that perform tasks at construction sites [102]. Robots are considered part of the work environment because they combine automation with cognitive skills [11].

At present time, robotics is being used to inspect civil structures [33] and to assemble pieces in the construction of wooden structures [34] and other tasks such as steel setup and brick or concrete block assembly [103]. Besides, the combination of widespread common devices, such as smartphones [35], together with aerial robotics, popularly known as drones, have made aerial coordination, monitoring, and inspection in real-time of construction sites possible.

Nevertheless, there are challenges that robotics must overcome. One of these is related to logistics for robots that work in a fixed location [87]. Other equally important challenges include safety in automated processes, task planning, and communicational situations between robots and humans [104].

\subsection{Virtual and Augmented Reality}

Virtual reality (VR) consists of systems that use a computer-generated scenario to simulate interactions between the user and a virtual environment in real-time. Since 1990, it has experienced remarkable growth, undergone development, and been applied in areas such as education and training [76]. 
When using VR in training related to the construction industry, it reduces the risks people may be exposed to [105], optimizes procedures, and makes it possible to identify danger zones [15].

Nonetheless, there are technical and practical challenges for virtual reality. One of these is when users experience adverse effects when subjected to VR environments, which is due to the conflict between what they see and what they perceive. Although the costs of installing VR systems have decreased, it still implies large financial investments. Additionally, once installed, another challenge is to find a proper way to implement it into productive processes [77].

Alternately, augmented reality (AR) can be defined as the mixture between the real and virtual worlds $[29,30]$. This technique uses optical or video visualization via fixed or portable screens.

AR technology is often described based on two ways of tracking information from the physical world: the first one comprises a real image linked to a marker that displays information; the second is based on location as given by a device's GPS in order to identify the positions where the information should be superimposed to the former image [78]. AR can combine activities, thus enabling the smooth transmission of information and modifying the analysis and use of the instructions received, making this technology especially suitable for tasks such as assembly of pieces in the construction site [106] or identification of areas and elements in need of maintenance, which is related to facility management in buildings [79].

As AR is used in architecture [80], maintenance and repair work [78], and other fields, it can also be combined with other technologies, such as BIM. Furthermore, it can improve preventive care when the tasks required are completed in the industrial and construction context [82].

The challenges for AR are related to external factors that affect the development of virtual environments, which are also related to so-called cybersickness (experienced in VR, not in AR) or the negative effects that workers and users may experience after using this technology [81].

Despite VR and AR adopting different approaches, some authors have identified fields where they can be used conjointly, such as safety in the construction site [82].

\subsection{New Materials Related to Industrialization}

There are a variety of new materials that have emerged in response to the interest in increasing production in construction and in protecting the environment, since this industry generates a large number of residues and waste products and depletes natural resources. Hence, the search began for materials that are sustainable throughout their life cycle, where natural biomaterials are one of the trends identified. They save on costs, are highly available, and meet the technical requirements for construction.

In this same context, research has been conducted into the use of agricultural by-products, such as biomass for the production of new biodegradable compounds, a clean source of energy in the benefit of local communities or an alternative to fossil fuel, highly used in construction machinery.

Another crucial issue of buildings during their lifecycle is repair and maintenance, where an innovative wager comes into play: self-repairing materials, which are capable of self-repair, thereby increasing their lifespan [107]. These techniques have also improved the properties of classical materials, such as concrete; thanks to the development of new techniques, it has been possible to address the matter of dynamic loads to predict possible flaws in structures of this material utilizing the numerical analysis of different parameters [83].

Every day, the construction industry is looking for new sources of energy that generate the least possible impact on the environment. One of these is hydrogen, which is used to transport energy. In this sense, new materials have emerged with hydrogen storage capacities superior to those in existence that comply with the necessary conditions required by the industry [84].

Special attention must be paid to one material that has revolutionized the industry in recent years: graphene, a monolayer of carbon atoms considered the thinnest material in the world and with advanced mechanical properties such as good conductivity, high resistance, as well as optical and electrical properties [85]. 
The main challenge that those materials face is compliance with actual technological standards and construction codes; their use is mainly restricted to the research domain or to the fabrication of pilot prototypes, and the next step should be their introduction into the commercial market of the construction industry.

In terms of how materials are assembled or built, from a 3D concrete printing perspective, concrete being traditionally cast is now an extruded cement-based mortar deposited layer-by-layer, where the material is required to flow and extrude through a nozzle, to bond with the previous layer, and to maintain its shape under increasing hydrostatic pressure generated by subsequent layer deposition [108]. Similarly, when talking about reinforcing steel, rebars being manually put together into cages in a traditional way are now a mesh mold metal assembled by robots-an innovative construction technique for bending, inserting, cutting, and welding the wires-based on innovation in materials science, structural engineering, and mechatronics, where the mesh is built more densely than traditional steel-reinforced concrete rebar cages, avoiding concrete flows through the mesh $[87,109]$. Another example may be found in the assembly of stay-in-place concrete blocks using a robot, a construction process performed by an industrial robotic arm, programmed to assemble the blocks according to the layout of a building, evidencing the speed and versatility of these types of robotic systems [103].

\section{Discussion}

This review aimed to perform an intensive review on the concept of Construction 4.0, which has been subject to intense debate during the last years. Around 260 publications from 130 different scientific journals have been analyzed through software for bibliometric analysis. Seven key concepts in relation to Construction 4.0 have been identified, along with a detailed analysis of the most relevant bibliometric trends. The main conclusions of this study are presented as follows:

The origin of the term Construction 4.0 has been traced back to year 2016, and the first mention of construction as a field of Industry 4.0 to 2014. However, the seven key concepts that aim at defining Construction 4.0 were devised before: IoT (1999), computer-aided design technologies (1960s), 3D printing (1980), big data (2011), artificial intelligence and robotics (1980s), and virtual and augmented reality (1990s); only in the case of new materials related to industrialization is the origin unclear. In such a way, Construction 4.0 could be defined as a dynamic cluster of concepts that were developed from the early 1980s, with big data being the most recent. The term was also first conceptualized as a particular application of the Industry 4.0 (2011) and, at the moment, is still trying to find its own definition.

It was hypothesized that those seven keywords would be descriptive of the term Construction 4.0, and this hypothesis has been proved to some extent. Four of the keywords were found to be centers of their own influential clusters: 3D printing, virtual reality, big data, and IoT, whereas three of them (new materials related to industrialization, artificial intelligence, and BIM) did not show that clear pattern. Therefore, it is suggested that, in the future, those terms should be reformulated to find stronger connections between them.

Besides, those publications are related not only to the classical domain of construction but also to concepts that, at first sight, might not bear relation with the construction industry. The limits between different scientific fields are becoming increasingly diffuse, and the present analysis points out that topics such as robotic construction, artificial intelligence, or virtual reality are starting to pervade in the construction industry.

That has also a wider implication for the concept of Construction 4.0 itself. Those concepts are not only adding a new feature to the construction market but also transforming the concept of construction itself. Although this industry has been traditionally labeled as unproductive, this review shows that this trend might be changing and that change is expected to be stronger in the near future. Conclusions from this review are in line with other similar studies $[3,4,7,13]$ which point out that Construction 4.0 will bring significant benefits in the management of engineering and construction projects. Furthermore, this study adds understanding to the state of affairs of the Construction 4.0 industry by updating and 
expanding the findings from similar studies from 2016, focusing on three concrete aspects: The number of publications from 2016 to present time has sharply increased, as this study compiles all that new information; some concepts, such as BIM, cloud computing, and big data, seem to be crucial for the understanding of Construction 4.0 in both reviews, whereas others seem to have gained momentum in recent times. In addition, the trend of publications found in this review shows that the construction industry will no longer be impervious to technological innovation behind the Construction 4.0 concept. Last, both studies seem to show that the countries which could lead this digital revolution in the construction industry are the USA, the UK, and China, with the highest number of publications, as well as Malaysia, with a prominent position; however, these findings do not allow building categorical conclusions, since not having a high number of publications does not necessarily imply not being a leader in Construction 4.0, where it is well known that innovation in construction robotics and robotic fabrication have been clearly driven by Europe, mainly by Switzerland and Germany, and by Japan.

That opens an interesting debate about the technological and scientific necessary background for the successful implementation of this digital transformation in the construction industry. This study has shown that Construction 4.0 needs a solid background, comprising advanced technological development, skilled labor, and an innovative legal framework that can deal with the new issues pertaining to the use of such technology; such an environment is expected to exist in developed economies, such as the top-three countries identified in both studies. However, it is remarkable how countries such as China and Malaysia are raising their voices in this digital transformation. It would be recommended to keep a closer look at these countries in the near future and to track their advances in this field.

\section{Conclusions}

This study has identified 7 key topics through a systematized review of a considerable number of recent publications, for which the number has remarkably increased from 2014 (20 publications related to those 7 key topics) to 2019 (82 publications). It has been also clarified that growth in the number of publications during the last 5 years can be approximated to an exponential function, a claim that is supported by similar reviews for related topics $[7,20,82,110]$. Since this term was recently coined, the time span of this review is quite short and, therefore, is it expected that the number of publications will experience a dramatic increase in the next years. It has been clarified that, at the present time, research on Construction 4.0 is dominated by two main poles of attraction: Asia, which is clearly dominated by China, and English-speaking countries, with the USA, England, and Australia dominating. Likewise, 5 key publications in terms of their number of citations have been identified as prominent in this field.

This finding may entail additional implications: First, it is suggested that reviews on this topic should be conducted every 3 years, at least, to capture the rapid and intense evolution of this industry. Second, this study appears to have also methodological implications because using bibliometric software and data-mining technologies allows for a deeper understanding of the trends and directions of this industry beyond the hard numbers of publications by journal, topic, or country, but their use requires a profound comprehension of the topic beforehand in order to conduct analyses properly. In this fashion, bibliometric maps greatly help in identifying those directions, allowing for a "soft" approach to this complex phenomenon. A classification based on 3 categories is proposed to support this approach: node, a concept that encompasses a great number of publications; hub, a concept that gathers a great number of connections; and bridge, a concept that is crucial for linking hubs and nodes. Following this approach and according to the results of this review, Internet of things and big data could be labeled as nodes and as hubs, because they are highly interconnected. Big data analytics and Industry 4.0 could be classified as hubs because, despite not gathering a great number of publications, they are highly interconnected. Finally, 2 concepts are clearly labeled as bridges in this study: construction industry and BIM; for example, if someone wants to understand how 3D printing and Internet of Things might be related, it would be necessary to resort to BIM to find a relation between them. From the point of view of the authors, this soft approach is much more productive 
when trying to grasp the complex relations between the different fields of knowledge involved in this industry.

Consequently, a question about the future challenges for this new industry arises in relation to these 7 key topics. Generally speaking, the main challenges that have been identified are related to 3 concrete aspects: automatization of the construction industry, dematerialization of buildings, and the interdisciplinary nature of new construction. Automatization to the construction industry will bring many benefits for sure, but as some of the reviewed publications point out, issues arise about the social costs associated with potential job losses or the ethical issues of letting AI decide on safety protocols on the construction site.

The review has also identified a concept that the authors would like to define as dematerialization of buildings, commonly related to "smart" homes but considered here in a wider sense, as the reduction in the amount of material resources required from a sustainable perspective. Construction and buildings, in general, have always been traditionally based on the concept of materiality, which separates the interior from the exterior; homes are spaces where privacy, security, and wellbeing are considered crucial. The implementation of these new technologies, especially the Internet of Things, brings new possibilities and functionalities for these homes but also serious issues pertaining to privacy and security; despite being an enclosed and private material space, the materiality of the building vanishes when it is equipped with a variety of devices that collects and send private data to external third parties. Dematerialization will also take place during the construction phase because, at some point, some technologies will not be present in the construction site. For example, a 3D printer occupies physical space in the construction site. However, we can imagine a system of inspecting drones connected to a wireless network for inspecting the plumbing system and sending data remotely to the design office where a group of engineers will check the installation using a VR system; this will not have a physical impact on the construction site but will lead to a radical change in the way construction is approached.

These concerns connect with the third identified challenge: the interdisciplinary nature of the new construction industry. This review relies on many journals for which scope might not be, at first sight, remotely related to the construction industry, but a wider look is needed to understand the changes in this area. The trend of publications shows that the construction industry will no longer be impervious to this technological innovation. Therefore, interdisciplinary studies, integrating at least these 7 key topics, are considered a must in the near future to understand the forthcoming changes. Journals related Not only to the construction industry but also to computer engineering, artificial intelligence, automatization, or even philosophy and anthropology should be included in future reviews. It is expected that a large amount of information arises, and future research should also focus on how to select different criteria to process, analyze, and categorize bibliographical information on a vast variety of topics. Despite the techniques and criteria presented in this review giving insightful information, the authors recognize that there is still much room for improvement in this regard.

This study has also faced some limitations. First, being a review on a very recent topic, concepts, technology, and knowledge are constantly evolving; it has been mentioned that studies on this topic should be conducted at least every 3 years, and it is expected that the applicability of the present review will be limited to that timespan. The definitions used as a starting point for this study and compiled in Table 2 are from 2016 to 2019, but many more may arise in the near future. Second, this review has a comprehensive approach from the point of view of civil engineers and architects, which is, in the view of the authors, beneficial for a study of its kind. It presented the conceptualization of seven keywords, their application to the construction industry, and the relation between them to build a map of knowledge for Construction 4.0; however, each of these keywords have a deep theoretical background that this study could not grasp in its entirety, and this calls for specific studies on each area conducted by specialists in the field (i.e., big data, robotics, artificial intelligence, etc.) in close cooperation with construction engineers and architects. Also, in the near future, after Construction 4.0 is properly conceptualized, reviews will be able to focus on other more specific topics to civil and 
construction engineering such as construction methods, tools, and materials. Finally, due to the limited scope of the study, the most prominent countries promoting advancement in Construction 4.0 were identified, but considerations about the local contexts were not included in the study. More research is deemed necessary to clarify how Construction 4.0 is being implemented in each country considering also the local regulatory framework and the practices of the construction industry.

The innovations, trends, and challenges identified in this study aim at being as comprehensive as possible in order to grasp the situation of Construction 4.0 at the present time. However, it seems that this industry is experiencing explosive growth due to the integration of new technologies, concepts, and approaches that will bring new conceptualization of the word "construction" in the next years. That is why a closer look should be kept on it to understand as soon as possible the changes that will take place in the near future.

Author Contributions: Conceptualization, E.F. and I.F.; methodology, A.O.-V. and J.A.P.-A.; funding acquisition, E.F.; validation, E.F., A.O.-V. and J.A.P.-A.; formal analysis, I.F.; investigation, E.F., I.F., A.O.-V. and J.A.P.-A.; supervision, E.F. and J.A.P.-A.; writing-review and editing, E.F., A.O.-V. and J.A.P.-A. All authors have read and agreed to the published version of the manuscript.

Funding: This research was partially supported by "Concurso de Ayudantes de Investigación 2020" from the Universidad del Bío-Bío, Chile.

Conflicts of Interest: The authors declare no conflict of interest.

\section{References}

1. Boyes, H.; Hallaq, B.; Cunningham, J.; Watson, T. The industrial internet of things (IIoT): An analysis framework. Comput. Ind. 2018, 101, 1-12. [CrossRef]

2. Berger, R. Roland Berger Digitization in the Construction Industry: Building Europe's Road to "Construction 4.0"; Roland Berger GMBH: Munich, Germany, 2016.

3. Sawhney, A.; Riley, M.; Irizarry, J. Construction 4.0-An Innovation Platform for the Built Environment; Routledge: New York, NY, USA, 2020; ISBN 978-0-429-39810-0.

4. Beddiar, K.; Grellier, C.; Woods, E. Construction 4.0: Réinventer le Bâtiment Grâce au Numérique: BIM, DfMA, Lean Management; Dunod: Paris, France, 2019; ISBN 2100790501.

5. Fokaides, P.A.; Apanaviciene, R.; Černeckienè, J.; Jurelionis, A.; Klumbyte, E.; Kriauciunaite-Neklejonoviene, V.; Pupeikis, D.; Rekus, D.; Sadauskiene, J.; Seduikyte, L.; et al. Research Challenges and Advancements in the field of Sustainable Energy Technologies in the Built Environment. Sustainability 2020, 12, 8417. [CrossRef]

6. Zavadskas, E.K.; Antuchevičiene, J.; Vilutiene, T.; Adeli, H. Sustainable Decision-Making in Civil Engineering, Construction and Building Technology. Sustainability 2017, 10, 14. [CrossRef]

7. Bock, T. The future of construction automation: Technological disruption and the upcoming ubiquity of robotics. Autom. Constr. 2015, 59, 113-121. [CrossRef]

8. De Soto, B.G.; Agustí-Juan, I.; Hunhevicz, J.; Joss, S.; Graser, K.; Habert, G.; Adey, B.T. Productivity of digital fabrication in construction: Cost and time analysis of a robotically built wall. Autom. Constr. 2018, 92, $297-311$. [CrossRef]

9. Hofmann, E.; Rüsch, M. Industry 4.0 and the current status as well as future prospects on logistics. Comput. Ind. 2017, 89, 23-34. [CrossRef]

10. Lasi, H.; Fettke, P.; Kemper, H.-G.; Feld, T.; Hoffmann, M. Industry 4.0. Bus. Inf. Syst. Eng. 2014, 6, $239-242$. [CrossRef]

11. Villani, V.; Pini, F.; Leali, F.; Secchi, C. Survey on human-robot collaboration in industrial settings: Safety, intuitive interfaces and applications. Mechatronics 2018, 55, 248-266. [CrossRef]

12. Li, Q.; Shi, J. Dam construction 4.0. J. Hydroelectr. Eng. 2015, 34, 1-6. [CrossRef]

13. Craveiro, F.; Duarte, J.P.; Bartolo, H.; Bartolo, P.J. Additive manufacturing as an enabling technology for digital construction: A perspective on Construction 4.0. Autom. Constr. 2019, 103, 251-267. [CrossRef]

14. Woodhead, R.; Stephenson, P.; Morrey, D. Digital construction: From point solutions to IoT ecosystem. Autom. Constr. 2018, 93, 35-46. [CrossRef] 
15. Atherinis, D.; Bakowski, B.; Velcek, M.; Moon, S. Developing and Laboratory Testing a Smart System for Automated Falsework Inspection in Construction. J. Constr. Eng. Manag. 2018, 144, 04017119. [CrossRef]

16. Seuring, S.; Gold, S. Conducting content-analysis based literature reviews in supply chain management. Supply Chain Manag. Int. J. 2012, 17, 544-555. [CrossRef]

17. Eguaras-Martínez, M.; Vidaurre-Arbizu, M.; Martín-Gómez, C. Simulation and evaluation of Building Information Modeling in a real pilot site. Appl. Energy 2014, 114, 475-484. [CrossRef]

18. Abanda, F.H.; Byers, L. An investigation of the impact of building orientation on energy consumption in a domestic building using emerging BIM (Building Information Modelling). Energy 2016, 97, 517-527. [CrossRef]

19. Johansson, M.; Roupé, M.; Boschsijtsema, P.M. Real-time visualization of building information models (BIM). Autom. Constr. 2015, 54, 69-82. [CrossRef]

20. Antwi-Afari, M.F.; Li, H.; Pärn, E.A.; Edwards, D.J. Critical success factors for implementing building information modelling (BIM): A longitudinal review. Autom. Constr. 2018, 91, 100-110. [CrossRef]

21. Zhang, C.; Nizam, R.S.; Tian, L. BIM-based investigation of total energy consumption in delivering building products. Adv. Eng. Inform. 2018, 38, 370-380. [CrossRef]

22. Kamel, E.; Memari, A.M. Review of BIM's application in energy simulation: Tools, issues, and solutions. Autom. Constr. 2019, 97, 164-180. [CrossRef]

23. Chong, H.Y.; Lee, C.-Y.; Wang, X. A mixed review of the adoption of Building Information Modelling (BIM) for sustainability. J. Clean. Prod. 2017, 142, 4114-4126. [CrossRef]

24. Peng, C. Calculation of a building's life cycle carbon emissions based on Ecotect and building information modeling. J. Clean. Prod. 2016, 112, 453-465. [CrossRef]

25. Martínez-Aires, M.D.; López-Alonso, M.; Martínez-Rojas, M. Building information modeling and safety management: A systematic review. Saf. Sci. 2018, 101, 11-18. [CrossRef]

26. Sun, C.; Jiang, S.; Skibniewski, M.J.; Man, Q.; Shen, L. A literature review of the factors limiting the application of BIM in the construction industry. Technol. Econ. Dev. Econ. 2017, 23, 764-779. [CrossRef]

27. Gerrish, T.; Ruikar, K.; Cook, M.J.; Johnson, M.; Phillip, M.; Lowry, C. BIM application to building energy performance visualisation and management: Challenges and potential. Energy Build. 2017, 144, 218-228. [CrossRef]

28. Abanda, F.H.; Vidalakis, C.; Oti, A.H.; Tah, J.H.M. A critical analysis of Building Information Modelling systems used in construction projects. Adv. Eng. Softw. 2015, 90, 183-201. [CrossRef]

29. Meža, S.; Turk, Ž.; Dolenc, M. Component based engineering of a mobile BIM-based augmented reality system. Autom. Constr. 2014, 42,1-12. [CrossRef]

30. Wang, X.; Truijens, M.; Hou, L.; Wang, Y.; Zhou, Y. Integrating Augmented Reality with Building Information Modeling: Onsite construction process controlling for liquefied natural gas industry. Autom. Constr. 2014, 40, 96-105. [CrossRef]

31. Aly, A.; Griffiths, S.; Stramandinoli, F. Metrics and benchmarks in human-robot interaction: Recent advances in cognitive robotics. Cogn. Syst. Res. 2017, 43, 313-323. [CrossRef]

32. Aly, A.; Griffiths, S.; Stramandinoli, F. Towards intelligent social robots: Current advances in cognitive robotics. Cogn. Syst. Res. 2017, 43, 153-156. [CrossRef]

33. Lattanzi, D.; Miller, G. Review of Robotic Infrastructure Inspection Systems. J. Infrastruct. Syst. 2017, 23, 1-16. [CrossRef]

34. Willmann, J.; Knauss, M.; Bonwetsch, T.; Apolinarska, A.A.; Gramazio, F.; Kohler, M. Robotic timber construction-Expanding additive fabrication to new dimensions. Autom. Constr. 2016, 61, 16-23. [CrossRef]

35. Bryson, J.J.; Winfield, A.F.T. Standardizing Ethical Design for Artificial Intelligence and Autonomous Systems. Computer 2017, 50, 116-119. [CrossRef]

36. Huang, M.-H.; Rust, R.T. Artificial Intelligence in Service. J. Serv. Res. 2018, 21, 155-172. [CrossRef]

37. Li, B.-H.; Hou, B.-C.; Yu, W.-T.; Lu, X.-B.; Yang, C.-W. Applications of artificial intelligence in intelligent manufacturing: A review. Front. Inf. Technol. Electron. Eng. 2017, 18, 86-96. [CrossRef]

38. Adat, V.; Gupta, B.B. Security in Internet of Things: Issues, challenges, taxonomy, and architecture. Telecommun. Syst. 2018, 67, 423-441. [CrossRef]

39. Al-Fuqaha, A.I.; Guizani, M.; Mohammadi, M.; Aledhari, M.; Ayyash, M. Internet of Things: A Survey on Enabling Technologies, Protocols, and Applications. IEEE Commun. Surv. Tutor. 2015, 17, 2347-2376. [CrossRef] 
40. Sun, Y.; Song, H.; Jara, A.J.; Bie, R. Internet of Things and Big Data Analytics for Smart and Connected Communities. IEEE Access 2016, 4, 766-773. [CrossRef]

41. Bibri, S.E. The IoT for smart sustainable cities of the future: An analytical framework for sensor-based big data applications for environmental sustainability. Sustain. Cities Soc. 2018, 38, 230-253. [CrossRef]

42. Din, I.U.; Guizani, M.; Rodrigues, J.J.P.C.; Hassan, S.; Korotaev, V.V. Machine learning in the Internet of Things: Designed techniques for smart cities. Future Gener. Comput. Syst. 2019, 100, 826-843. [CrossRef]

43. Rahmani, A.M.; Gia, T.N.; Negash, B.; Anzanpour, A.; Azimi, I.; Jiang, M.; Liljeberg, P. Exploiting smart e-Health gateways at the edge of healthcare Internet-of-Things: A fog computing approach. Future Gener. Comput. Syst. 2018, 78, 641-658. [CrossRef]

44. Chen, M.; Mao, S.; Liu, Y. Big Data: A Survey. Mob. Netw. Appl. 2014, 19, 171-209. [CrossRef]

45. Ge, M.; Bangui, H.; Buhnova, B. Big Data for Internet of Things: A Survey. Future Gener. Comput. Syst. 2018, 87, 601-614. [CrossRef]

46. Caron, X.; Bosua, R.; Maynard, S.B.; Ahmad, A. The Internet of Things (IoT) and its impact on individual privacy: An Australian perspective. Comput. Law Secur. Rev. 2016, 32, 4-15. [CrossRef]

47. Díaz, M.; Martín, C.; Rubio, B. State-of-the-art, challenges, and open issues in the integration of Internet of things and cloud computing. J. Netw. Comput. Appl. 2016, 67, 99-117. [CrossRef]

48. Borgia, E. The Internet of Things vision: Key features, applications and open issues. Comput. Commun. 2014, 54, 1-31. [CrossRef]

49. Botta, A.; De Donato, W.; Persico, V.; Pescape, A. Integration of Cloud computing and Internet of Things: A survey. Future Gener. Comput. Syst. 2016, 56, 684-700. [CrossRef]

50. Da Xu, L.; He, W.; Li, S. Internet of Things in Industries: A Survey. IEEE Trans. Ind. Informatics 2014, 10, 2233-2243. [CrossRef]

51. Plageras, A.P.; Psannis, K.E.; Stergiou, C.; Wang, H.; Gupta, B.B. Efficient IoT-based sensor BIG Data collection-processing and analysis in smart buildings. Future Gener. Comput. Syst. 2018, 82, 349-357. [CrossRef]

52. Wortmann, A.-P.D.F.; Flüchter, K. Internet of Things. Bus. Inf. Syst. Eng. 2015, 57, 221-224. [CrossRef]

53. Chiarello, F.; Trivelli, L.; Bonaccorsi, A.; Fantoni, G. Extracting and mapping industry 4.0 technologies using wikipedia. Comput. Ind. 2018, 100, 244-257. [CrossRef]

54. Ni, J.; Zhang, K.; Lin, X.; Shen, X. Securing Fog Computing for Internet of Things Applications: Challenges and Solutions. IEEE Commun. Surv. Tutor. 2018, 20, 601-628. [CrossRef]

55. Zanella, A.; Bui, N.; Castellani, A.; Vangelista, L.; Zorzi, M. Internet of Things for Smart Cities. IEEE Internet Things J. 2014, 1, 22-32. [CrossRef]

56. Da Costa, K.A.P.; Papa, J.P.; Lisboa, C.O.; Munoz, R.; De Albuquerque, V.H.C. Internet of Things: A survey on machine learning-based intrusion detection approaches. Comput. Netw. 2019, 151, 147-157. [CrossRef]

57. Kouicem, D.E.; Bouabdallah, A.; Lakhlef, H. Internet of things security: A top-down survey. Comput. Netw. 2018, 141, 199-221. [CrossRef]

58. Conti, M.; Dehghantanha, A.; Franke, K.; Watson, S. Internet of Things security and forensics: Challenges and opportunities. Future Gener. Comput. Syst. 2018, 78, 544-546. [CrossRef]

59. Gandomi, A.; Haider, M. Beyond the hype: Big data concepts, methods, and analytics. Int. J. Inf. Manag. 2015, 35, 137-144. [CrossRef]

60. Assunção, M.D.; Calheiros, R.N.; Bianchi, S.; Netto, M.A.S.; Buyya, R. Big Data computing and clouds: Trends and future directions. J. Parallel Distrib. Comput. 2015, 3-15. [CrossRef]

61. George, G.; Haas, M.R.; Pentland, A. Big data and management. Acad. Manag. J. 2014, 57, 321-326. [CrossRef]

62. Bilal, M.; Oyedele, L.O.; Qadir, J.; Munir, K.; Ajayi, S.O.; Akinade, O.O.; Owolabi, H.A.; Alaka, H.A.; Pasha, M. Big Data in the construction industry: A review of present status, opportunities, and future trends. Adv. Eng. Inform. 2016, 30, 500-521. [CrossRef]

63. Bello-Orgaz, G.; Jung, J.J.; Camacho, D. Social big data: Recent achievements and new challenges. Inf. Fusion 2016, 28, 45-59. [CrossRef]

64. Zhang, Q.; Yang, L.T.; Chen, Z.; Li, P. A survey on deep learning for big data. Inf. Fusion 2018, 42, $146-157$. [CrossRef]

65. Lee, I. Big data: Dimensions, evolution, impacts, and challenges. Bus. Horiz. 2017, 60, 293-303. [CrossRef]

66. Côrte-Real, N.; Oliveira, T.; Ruivo, P. Assessing business value of Big Data Analytics in European firms. J. Bus. Res. 2017, 70, 379-390. [CrossRef] 
67. Weller, C.; Kleer, R.; Piller, F.T. Economic implications of 3D printing: Market structure models in light of additive manufacturing revisited. Int. J. Prod. Econ. 2015, 164, 43-56. [CrossRef]

68. Gosselin, C.; Duballet, R.; Roux, P.; Gaudillière, N.; Dirrenberger, J.; Morel, P. Large-scale 3D printing of ultra-high performance concrete-A new processing route for architects and builders. Mater. Des. 2016, 100, 102-109. [CrossRef]

69. Jiang, R.; Kleer, R.; Piller, F.T. Predicting the future of additive manufacturing: A Delphi study on economic and societal implications of 3D printing for 2030. Technol. Forecast. Soc. Chang. 2017, 117, 84-97. [CrossRef]

70. Asprone, D.; Auricchio, F.; Menna, C.; Mercuri, V. 3D printing of reinforced concrete elements: Technology and design approach. Constr. Build. Mater. 2018, 165, 218-231. [CrossRef]

71. Wu, P.; Wang, J.; Wang, X. A critical review of the use of 3-D printing in the construction industry. Autom. Constr. 2016, 68, 21-31. [CrossRef]

72. Paul, S.C.; Tay, Y.W.D.; Panda, B.; Tan, M.J. Fresh and hardened properties of 3D printable cementitious materials for building and construction. Arch. Civ. Mech. Eng. 2018, 18, 311-319. [CrossRef]

73. De Schutter, G.; Lesage, K.; Mechtcherine, V.; Nerella, V.N.; Habert, G.; Agusti-Juan, I. Vision of 3D printing with concrete-Technical, economic and environmental potentials. Cem. Concr. Res. 2018, 112, 25-36. [CrossRef]

74. Oropallo, W.; Piegl, L.A. Ten challenges in 3D printing. Eng. Comput. 2016, 32, 135-148. [CrossRef]

75. Qi, Q.; Tao, F. Digital Twin and Big Data Towards Smart Manufacturing and Industry 4.0: 360 Degree Comparison. IEEE Access 2018, 6, 3585-3593. [CrossRef]

76. Gavish, N.; Gutiérrez, T.; Webel, S.; Rodríguez, J.; Peveri, M.; Bockholt, U.; Tecchia, F. Evaluating virtual reality and augmented reality training for industrial maintenance and assembly tasks. Interact. Learn. Environ. 2015, 23, 778-798. [CrossRef]

77. Berg, L.P.; Vance, J.M. Industry use of virtual reality in product design and manufacturing: A survey. Virtual Real. 2017, 21, 1-17. [CrossRef]

78. Koch, C.; Neges, M.; König, M.; Abramovici, M. Natural markers for augmented reality-based indoor navigation and facility maintenance. Autom. Constr. 2014, 48, 18-30. [CrossRef]

79. Liu, F.; Seipel, S. Precision study on augmented reality-based visual guidance for facility management tasks. Autom. Constr. 2018, 90, 79-90. [CrossRef]

80. Fazel, A.; Izadi, A. An interactive augmented reality tool for constructing free-form modular surfaces. Autom. Constr. 2018, 85, 135-145. [CrossRef]

81. Rebenitsch, L.; Owen, C.B. Review on cybersickness in applications and visual displays. Virtual Real. 2016, 20, 101-125. [CrossRef]

82. Li, X.; Yi, W.; Chi, H.-L.; Wang, X.; Chan, A.P.C. A critical review of virtual and augmented reality (VR/AR) applications in construction safety. Autom. Constr. 2018, 86, 150-162. [CrossRef]

83. Kong, X.; Fang, Q.; Chen, L.; Wu, H. A new material model for concrete subjected to intense dynamic loadings. Int. J. Impact Eng. 2018, 120, 60-78. [CrossRef]

84. Xueping, Z.; Jiaojiao, Z.; Shenglin, L.; Xuanhui, Q.; Ping, L.; Yanbei, G.; Weihua, L. A new solid material for hydrogen storage. Int. J. Hydrogen Energy 2015, 40, 10502-10507. [CrossRef]

85. Mahmoudi, T.; Wang, Y.; Hahn, Y.-B. Graphene and its derivatives for solar cells application. Nano Energy 2018, 47, 51-65. [CrossRef]

86. Muth, J.T.; Vogt, D.M.; Truby, R.L.; Mengüç, Y.; Kolesky, D.B.; Wood, R.J.; Lewis, J.A. Embedded 3D Printing of Strain Sensors within Highly Stretchable Elastomers. Adv. Mater. 2014, 26, 6307-6312. [CrossRef]

87. Buchli, J.; Giftthaler, M.; Kumar, N.; Lussi, M.; Sandy, T.; Dörfler, K.; Hack, N. Digital in situ fabrication-Challenges and opportunities for robotic in situ fabrication in architecture, construction, and beyond. Cem. Concr. Res. 2018, 112, 66-75. [CrossRef]

88. Kehoe, B.; Patil, S.; Abbeel, P.; Goldberg, K. A Survey of Research on Cloud Robotics and Automation. IEEE Trans. Autom. Sci. Eng. 2015, 12, 398-409. [CrossRef]

89. Li, R.; Zhao, Z.; Zhou, X.; Ding, G.; Chen, Y.; Wang, Z.; Zhang, H. Intelligent 5G: When Cellular Networks Meet Artificial Intelligence. IEEE Wirel. Commun. 2017, 24, 175-183. [CrossRef]

90. Sicari, S.; Rizzardi, A.; Grieco, L.A.; Coenporisini, A. Security, privacy and trust in Internet of Things: The road ahead. Comput. Netw. 2015, 76, 146-164. [CrossRef]

91. Lu, H.; Li, Y.; Chen, M.; Kim, H.; Serikawa, S. Brain Intelligence: Go beyond Artificial Intelligence. Mob. Netw. Appl. 2018, 23, 368-375. [CrossRef] 
92. Zareiyan, B.; Khoshnevis, B. Effects of interlocking on interlayer adhesion and strength of structures in $3 \mathrm{D}$ printing of concrete. Autom. Constr. 2017, 83, 212-221. [CrossRef]

93. Lee, I.; Lee, K. The Internet of Things (IoT): Applications, investments, and challenges for enterprises. Bus. Horiz. 2015, 58, 431-440. [CrossRef]

94. Ng, I.C.L.; Wakenshaw, S.Y.L. The Internet-of-Things: Review and research directions. Int. J. Res. Mark. 2017, 34, 3-21. [CrossRef]

95. Noor, M.M.; Hassan, W.H. Current research on Internet of Things (IoT) security: A survey. Comput. Netw. 2019, 148, 283-294. [CrossRef]

96. Carvalho, J.P.; Bragança, L.; Mateus, R. Optimising building sustainability assessment using BIM. Autom. Constr. 2019, 102, 170-182. [CrossRef]

97. Ding, Z.; Liu, S.; Liao, L.; Zhang, L. A digital construction framework integrating building information modeling and reverse engineering technologies for renovation projects. Autom. Constr. 2019, 102, 45-58. [CrossRef]

98. Xia, M.; Nematollahi, B.; Sanjayan, J. Printability, accuracy and strength of geopolymer made using powder-based 3D printing for construction applications. Autom. Constr. 2019, 101, 179-189. [CrossRef]

99. Hosseini, E.; Zakertabrizi, M.; Korayem, A.H.; Xu, G. A novel method to enhance the interlayer bonding of 3D printing concrete: An experimental and computational investigation. Cem. Concr. Compos. 2019, 99, 112-119. [CrossRef]

100. Osman, A.M.S. A novel big data analytics framework for smart cities. Future Gener. Comput. Syst. 2019, 91, 620-633. [CrossRef]

101. Rehman, M.H.U.; Yaqoob, I.; Salah, K.; Imran, M.; Jayaraman, P.P.; Perera, C. The role of big data analytics in industrial Internet of Things. Future Gener. Comput. Syst. 2019, 99, 247-259. [CrossRef]

102. Lundeen, K.M.; Kamat, V.R.; Menassa, C.C.; McGee, W. Autonomous motion planning and task execution in geometrically adaptive robotized construction work. Autom. Constr. 2019, 100, 24-45. [CrossRef]

103. García, R.; Perez, A.; Pulido, J.A.; Ulloa, P.; Forcael, E. Assembly of Stay-In-Place Concrete Blocks Using a Robot. IOP Conf. Series Earth Environ. Sci. 2020, 503, 012077. [CrossRef]

104. Liang, C.-J.; Lundeen, K.M.; McGee, W.; Menassa, C.C.; Lee, S.; Kamat, V.R. A vision-based marker-less pose estimation system for articulated construction robots. Autom. Constr. 2019, 104, 80-94. [CrossRef]

105. Shi, Y.; Du, J.; Ahn, C.R.; Ragan, E. Impact assessment of reinforced learning methods on construction workers' fall risk behavior using virtual reality. Autom. Constr. 2019, 104, 197-214. [CrossRef]

106. Kwiatek, C.; Sharif, M.; Li, S.; Haas, C.T.; Walbridge, S. Impact of augmented reality and spatial cognition on assembly in construction. Autom. Constr. 2019, 108, 102935. [CrossRef]

107. Norambuena-Contreras, J.; Liu, Q.; Zhang, L.; Wu, S.; Yalcin, E.; Garcia, A. Influence of encapsulated sunflower oil on the mechanical and self-healing properties of dense-graded asphalt mixtures. Mater. Struct. 2019, 52, 78. [CrossRef]

108. Buswell, R.A.; De Silva, W.R.L.; Jones, S.Z.; Dirrenberger, J. 3D printing using concrete extrusion: A roadmap for research. Cem. Concr. Res. 2018, 112, 37-49. [CrossRef]

109. Hack, N.P. Mesh Mould: A Robotically Fabricated Structural Stay-in-Place Formwork System. Ph.D. Thesis, ETH Zürich, Zürich, Germany, 2018.

110. Abdelmegid, M.A.; González, V.A.; Poshdar, M.; O'Sullivan, M.; Walker, C.G.; Ying, F. Barriers to adopting simulation modelling in construction industry. Autom. Constr. 2020, 111, 103046. [CrossRef]

Publisher's Note: MDPI stays neutral with regard to jurisdictional claims in published maps and institutional affiliations.

(C) 2020 by the authors. Licensee MDPI, Basel, Switzerland. This article is an open access article distributed under the terms and conditions of the Creative Commons Attribution (CC BY) license (http://creativecommons.org/licenses/by/4.0/). 